Hispania Sacra, LIX

120, julio-diciembre 2007, 563-594, ISSN: 0018-215-X

\title{
CLÉRIGOS A LA SOMBRA DE UN PARIENTE EN EL XVIII BURGALÉS
}

\author{
POR \\ FrANCISCO J. SANZ DE LA HigUERA \\ I. E. S. «Torreblanca» (Sevilla)*
}

\begin{abstract}
RESUMEN
El Catastro de Ensenada contiene, en el interior de los gruesos volúmenes de las Respuestas Particulares o Memoriales, una detallada descripción de los parámetros vitales del clero. La fórmula habitual es ocuparse de los eclesiásticos con vivienda independiente y estudiar sus actividades profesionales. No obstante, también descubrimos la existencia de clérigos que, por diversas circunstancias, estaban obligados a vivir bajo la férula de algún pariente, entre las paredes de sus hogares y a la sombra de sus quehaceres. ¿Cuántos son? ¿En qué estructuras domésticas se albergaban? ¿Cuáles eran sus actividades profesionales? ¿Qué impacto tenía su presencia en los hogares que les daban cobijo? ¿En qué colaciones y calles habitaban?
\end{abstract}

PALABRAS ClAVE: Clérigo, Hogar, Catastro de Ensenada, Colación.

\begin{abstract}
The Catastro of Ensenada contains, inside the thick volumes of the Respuestas Particulares or Memoriales, a detailed description of the vital parameters of the clergy. The usual formula is to take care of the ecclesiastical with independent housing and to study their professional activities. However, we also discovered the existence of clergy who, by different circumstances, are forced to live under the order of any close relation, within the walls of their own households and under the shadow of their own business. How many are they?
\end{abstract}

* I. E. S. «Torreblanca», C/Torregrosa, 85, 41016 SEVILLA. A mis compañeras y compañeros de trabajo, por su afecto y solidaridad y porque me confirman cotidianamente que la igualdad no es un experimento dañino sino una experiencia humana maravillosa aunque a veces difícil de conseguir. 
What were their household structures? What were their professional activities? What impact did their presence in the household which gave them shelter? What colaciones and streets did they live?

KEY WORDS: Clergy, Household, Catastro of Ensenada, Colación.

Recibido/Received 21-09-2006

Aceptado/Accepted 05-11-2006

\section{INTRODUCCIÓN Y FUENTES DOCUMENTALES}

Sobre el clero en la España del siglo XVIII se han escrito múltiples páginas de muy diferente talante y contenido, bibliografía que no es el momento de reseñar de forma detallada. Un aspecto esencial de su historia particular, imbricado en el acontecer global del Antiguo Régimen, era la peculiar manera que tenían de entender el hogar y la convivencia tales eclesiásticos, circunstancias que deben ligarse indisolublemente a su estado civil, a sus contabilidades y vicisitudes profesionales y al espacio que para la corresidencia generaban en sus propias viviendas. Resulta imprescindible consultar, para profundizar en sus idiosincrasias y quehaceres, los trabajos de Dubert García, Barreiro Mallón, Rey Castelao, Morgado García, Benito Aguado, Bravo Lozano, Candau Chacón, Irigoyen López, por citar, sin un carácter exhaustivo, los más significativos y descollantes ${ }^{1}$.

\footnotetext{
${ }^{1}$ I. DUBERT GARCíA: «Los comportamientos familiares del clero urbano en Galicia: el ejemplo de Santiago de Compostela en el siglo XVIII», Compostellanum, núm. 31 (1986), Santiago de Compostela, pp. 443-456, Historia de la familia en Galicia durante la época Moderna, 1550-1830, La Coruña, 1992 (en especial las pp. 167-176, «Un caso especial: La vida familiar del clero gallego a mediados del siglo XVIII»), «Alma de curas y Cura de almas. Moral y comportamientos eclesiásticos en la Galicia interior durante el Antiguo Régimen (1600-1830)», Semata, núm. 8-8, Santiago de Compostela, pp. 379-411, y «El clero rural en Galicia a fines del Antiguo Régimen», Homenaje a José García Oro, pp. 101-118. B. BARREIRo MALlóN: «Las clases urbanas de Santiago en el siglo XVIII: definición de un estilo de vida y de pensamiento», La historia social de Galicia en sus fuentes de protocolos, Santiago de Compostela, 1981, pp. 449-493, (en especial, 453-460), «El clero de la diócesis de Santiago: estructura y comportamientos», Compostellanum, núm. 33 (1988), Santiago de Compostela, pp. 469-507. O. REY CASTELAO: «El clero urbano compostelano a fines del siglo XVII: mentalidades y hábitos culturales», La historia social de Galicia en sus fuentes de protocolos, Santiago de Compostela, 1981, pp. 495-519. A. Morgado García: Iglesia y Sociedad en el Cádiz del siglo XVIII, Cádiz, 1989, El clero gaditano a fines del Antiguo Régimen, Cádiz, 1989 y Ser clérigo en la España del Antiguo Régimen, Cádiz, 2000. M. T. Benito AgUAdo: La sociedad vitoriana en el siglo XVIII: El clero, espectador y protagonista, Bilbao, 2001. J. BRAVO LOZANO: «Cura rico/cura pobre. Notas sobre rentas eclesiásticas en el Madrid de fines del siglo XVII», E. MARTínez RuIZ y V. SuÁrez Grimón (Eds), Iglesia y Sociedad en el Antiguo Régimen. III Reunión Científica AEHM. Vol. I, Las Palmas de Gran Canaria, 1994, pp. 129-139. M. L. CANDAU CHACÓN: La carrera eclesiástica en el siglo XVIII, Sevilla, 1993 y A. IRIGOYEN LóPEZ, «Servicio doméstico de clérigos y clérigos en el servicio doméstico: el caso de Murcia en el Edad Moderna», (2006), Murcia. Véase también F. J. Aranda Pérez (Coord.): Sociedad y élites eclesiásticas en la España Moderna, Cuenca, 2000.
}

Hispania Sacra, LIX

120, julio-diciembre 2007, 563-594, ISSN: 0018-215-X 
Con objeto de llegar al conocimiento de quiénes y cuántos fueron, en qué lugar y de qué forma vivían y de dónde procedían sus ingresos -y cuáles eran los gastos imprescindibles y habituales- se han manejado varias fuentes documentales, cada una de ellas aporta un bagaje substancial y complementario. Descuellan especialmente los Memoriales, o Respuestas Particulares, del Catastro elaborado a instancias del marqués de Ensenada ${ }^{2}$, los libros de redondo de la mesa capitular de la Catedral de Burgos ${ }^{3}$, los protocolos notariales ${ }^{4}$, los libros de reparto de prebendas de las parroquias, capillas y congregaciones, los libros de tazmías y fábrica de las parroquias de la ciudad y de la provincia y los libros de matrícula pascual de varias parroquias urbanas 5 , además de otras localizaciones puntuales en los Archivos Históricos Provinciales de varias provincias ${ }^{6}$. De todos estos yacimientos de datos surge un enorme caudal informativo que permite reconstruir la vida cotidiana del clero en el Setecientos y contrastarla con la de los demás vecinos laicos, en el seno de una ciudad pre-industrial castellana, marginal, periférica y venida a menos.

Merced al Catastro es posible averiguar cuántos eran, quién o quienes eran las personas que les acompañaban, cuál era el carácter de su convivencia -incluido, con los pros y los contras que se desee, el servicio doméstico que tenían contratado-, qué tamaño y qué estructura tenían los hogares de los clérigos en función de su ubicación urbana, la edad del firmante del memorial o del útil ó alcance que se le puede calcular al hogar anualmente ${ }^{7}$ y la existencia de com-

2 El Catastro del marqués de la Ensenada de la ciudad de Burgos, y de toda la provincia, se encuentra magnífica y celosamente custodiado en el Archivo de la Diputación Provincial de Burgos - en lo sucesivo citado como ADPB, Catastro, Memoriales-.

${ }^{3}$ La documentación del Cabildo catedralicio se halla en el Archivo Capitular de la Catedral de Burgos. En las próximas referencias puntuales se citará como ACC, Libros de Redondo, en especial por lo tocante a la economía de los miembros de la Santa Iglesia Metropolitana.

4 Véase el Archivo Histórico Provincial de Burgos (AHPB), Protocolos Notariales (PN) con los escribanos, legajos, fechas y folios que puntualmente se irán desgranando a lo ancho y largo del artículo.

${ }^{5}$ El Archivo Diocesano de Burgos (en adelante ADB) es rico en sacramentales y en documentación económica del clero (tazmías, prebendas, etc.). Se citarán de forma exhaustiva y detallada las parroquias y las secciones en que se ha consultado la documentación pertinente.

${ }^{6} \mathrm{He}$ recibido o consultado información sobre los clérigos residentes en Burgos a mediados del XVIII del Archivo Histórico Provincial (AHP) de Ávila, del AHP de La Rioja y del AHP de Santander, documentación que ha permitido completar el volumen de sus ingresos y gastos.

${ }^{7} \mathrm{El}$ útil o alcance anual de cada hogar, y de los componentes del mismo, es el resultado último de una labor contable básica de sus ingresos y gastos, rastreados en todos aquellos documentos a que se ha podido acceder en el devenir de la investigación. Por lo tocante a los clérigos, se ha perseguido hasta la extenuación conocer, con el hilo conductor del Catastro como guía de búsqueda, cuánto percibían en las instituciones en las que sabemos trabajaban o cuáles eran las rentas que en otras localidades tenían a su disposición - merced a una revisión sistemática de los memoriales catastrales, de sus inventarios post-mortem y sus últimas voluntades-. Se han contemplado como gastos imprescindibles y obligados el abono del alquiler anual, los desembolsos en servidumbre (personal contratado), el pago del subsidio y el excusado, etc. Aunque el procedimiento está abierto, de manera flexible, a cualquier posible nueva aparición, consideramos que se ha llegado a un óptimo grado de veracidad y casi completa secuenciación de sus percepciones y desembolsos. 
portamientos y conductas diferenciales en función de su rango y estatus. Lamentablemente, el Catastro de la ciudad de Burgos no permite, salvo en contadas y exquisitas ocasiones, conocer la contabilidad personal de los clérigos. Ha sido preciso acudir a los lugares de procedencia de sus ingresos y gastos, en la Catedral, en las parroquias - de la ciudad y de un abultado listado de pueblos-, en los conventos y en el impresionante enjambre de capellanías, cofradías y congregaciones que poblaban el entramado urbano burgalés, para reconstruir, en la medida de lo posible, sus niveles de rentas y fortuna. Las Respuestas Generales y Particulares de múltiples villas y pueblos -no sólo de la actual provincia de Burgos- han sido, junto con los repartos de diezmos de las mesas parroquiales, herramientas insustituibles en el rastreo y conocimiento de dónde obtenían sus ingresos.

El sentido de estas páginas no es analizar la vida y el tamaño y estructura del hogar del clero burgalés con vivienda independiente ${ }^{8}$ sino las peculiaridades de los clérigos que convivían bajo el techo de otros familiares que los tenían acogidos y con quienes colaboraban al sostenimiento de las unidades domésticas. A través de sus propios memoriales o de los redactados por los parientes que les albergaban, nos llega noticia de su existencia y vicisitudes. No se traen a colación los clérigos que trabajaban a las órdenes de personalidades eclesiásticas relevantes ${ }^{9}$ ni a aquellos que estaban fuera de Burgos y en proceso de formación ${ }^{10}$ ni a los jóvenes que se encontraban en camino de religión pero aún no habían accedido al rango de presbíteros ${ }^{11}$. Los aquí reseñados son individuos

\footnotetext{
${ }^{8}$ En avanzado proceso de redacción se encuentra «El hogar del clérigo», que pretende contrastar la estructura y volumen de los establecimientos domésticos comandados por eclesiásticos en varias ciudades españolas, en especial Murcia, Santiago de Compostela y Burgos. Véase la bibliografía citada en la nota 2, en especial A. IRIGOYEN LÓPEZ (2006).

${ }^{9}$ F. J. SANZ DE LA HigUeRA: «Un capellán que sirve la mesa» y otros menesteres. Burgos a mediados del siglo XVIII», Stvdia Historica. Historia Moderna, núm. 24 (2002), Salamanca, pp. 331-362. Véase también el citado A. IRIGOYEN LóPEZ (2006): «Clérigos domésticos», s/p.

10 Tanto don Pedro Tomé González como don Francisco Castillo Castañeda, dos personajes de notable influencia en la socio-economía de la ciudad de Burgos durante gran parte del XVIII, tenían un hijo -el destinado a ser clérigo- «en Roma a pretensión de Renta Eclesiástica». Es significativo que sólo ellos dos, el cajero de sisas de la Dirección General de Rentas y procurador del número y el Administrador General de la Santa Cruzada y empresario ganadero, sean, de entre todos los vecinos acaudalados y componentes de las élites de gobierno, quienes se permitieran semejantes desembolsos. ADPB. Catastro, Memoriales, P, Libro 347, folios 92-96 y F, Libro 344, folio 994.

${ }^{11}$ Ejemplos de ello, de entre los muchos posibles, son el hijo de Casilda Ruiz, «estudiante de teología y ordenado de prima que asiste a un religioso de San Juan con enfermedad habitual y peligrosa», ADPB. Catastro, Memoriales, C, Libro 344, folio 549, el segundo hijo del conde de Villariezo, don José Ventura, empeñado en «estudios con renta eclesiástica y con intención de pasar al Estado Sacerdotal», Ibídem, A, Libro 344, folios 3-9 o un sobrino de Santiago Saez, «ordenado de primera tonsura y Capellán en la capellanía de Urrez sin Renta por el deterioro económico». Ibídem, S, Libro 347, folio 309. De este mismo tenor es el caso que se les presentaba a un hijo de doña Gertrudis González, don Juan, de 19 años, «clérigo de menores órdenes, cursante en la Sagrada teología en el convento de San
}

Hispania Sacra, LIX

120, julio-diciembre 2007, 563-594, ISSN: 0018-215-X 
que eran sacerdotes y, a través de una media ración, un beneficio o un canonicato, obtenían unas prebendas, y unos ingresos económicos de manera autónoma pero todavía no se habían separado físicamente de sus progenitores o vivían, en un funcional hermanamiento, junto a sus parientes cercanos, en una corresidencia fluida y gratificante para todos los cobijados entre las mismas paredes.

\section{EN CASA, MESA, CAMA Y COMPAÑ̃ÍA DE UN PARIENTE}

CUADRO I. Quehaceres profesionales y estructura del hogar. Clérigos con vivienda independiente. Burgos (1751)

\begin{tabular}{|c|c|c|c|c|c|c|c|c|}
\hline \multicolumn{9}{|c|}{ TIPOLOGÍA DE LOS HOGARES (Laslett) } \\
\hline & \multicolumn{4}{|c|}{ Solitarios (TIPO 1) } & \multicolumn{4}{|c|}{ Sin estructura familiar (TIPO 2) } \\
\hline & $\begin{array}{l}\text { Número } \\
\text { hogares }\end{array}$ & $\%$ & $\begin{array}{c}\text { Alcance } \\
\text { anual }\end{array}$ & $\mathrm{m}^{2}$ Hogar & $\begin{array}{l}\text { Número } \\
\text { hogares }\end{array}$ & $\%$ & $\begin{array}{c}\text { Alcance } \\
\text { anual }\end{array}$ & $\mathrm{m}^{2}$ Hogar \\
\hline CLERO BAJO & 4 & 22,2 & 1066 & 75,8 & 10 & 55,6 & 1467 & 178,5 \\
\hline CLERO MEDIO & & & & & 102 & 79,1 & 2394 & 157,8 \\
\hline CLERO ALTO & & & & & 35 & 81,4 & 9428 & 507,8 \\
\hline \multirow[t]{3}{*}{ TOTAL } & 4 & 2,1 & 1066 & 75,8 & 147 & 77,4 & 4005 & 242,6 \\
\hline & \multicolumn{4}{|c|}{ Ensanchados (TIPO 4) } & \multicolumn{4}{|c|}{ Múltiples (TIPO 5) } \\
\hline & $\begin{array}{l}\text { Número } \\
\text { hogares }\end{array}$ & $\%$ & $\begin{array}{c}\text { Alcance } \\
\text { anual }\end{array}$ & $\mathrm{m}^{2}$ Hogar & $\begin{array}{l}\text { Número } \\
\text { hogares }\end{array}$ & $\%$ & $\begin{array}{c}\text { Alcance } \\
\text { anual }\end{array}$ & $\mathrm{m}^{2}$ Hogar \\
\hline CLERO BAJO & & & & & 4 & 22,2 & 1558 & 151,2 \\
\hline CLERO MEDIO & 1 & 0,8 & 3052 & 94,1 & 26 & 20,1 & 3373 & 231,1 \\
\hline CLERO ALTO & & & & & 8 & 18,6 & 14246 & 488,3 \\
\hline TOTAL & 1 & 0,5 & 3052 & 94,1 & 38 & 20,1 & 5471 & 276,8 \\
\hline
\end{tabular}

Fuente: ADPB. Catastro. Memoriales. Libros 348 y 349.

Pablo [Burgos]; aunque tiene colacionada una Capellanía en la villa de Villasandino y tomada posesión de ella, no goza Renta alguna por ser cláusula de fundación que lo perciban los patronos de ella hasta que dho capellán no esté ordenado de epístola y en este estado sólo goce de la mitad hasta que se ordene y consiga el presbiteriado». Ibídem, G, Libro 345, folios 246-247. Véase B. BARREIRO MALLÓN: «El clero de la diócesis de Santiago...», Op. Cit., pp. 496-499, E. Fernández CubEIro: «Una práctica de la sociedad rural: aproximación al estudio de las capellanías de la Diócesis Compostelana en los siglos XVII y XVIII», La Historia social de Galicia... (1991), pp. 205ss y J. Pro: «Las capellanías: familia, Iglesia y propiedad en el Antiguo Régimen», Hispania Sacra, Madrid, (1989), pp. 585602 . 
Eran, en total, 43 clérigos que se acogían en 36 hogares. Ello supone un $15.9 \%$ de los eclesiásticos que bullían por las calles y las casas de la ciudad. Otras 190 unidades domésticas, el restante $84.1 \%$, estaban comandadas por clérigos que, de forma independiente, aparecían a la cabeza de un núcleo de convivencia, en corresidencia con familiares y/o servicio doméstico. El clero burgalés -véase CUADRO I- se recogía predominantemente en hogares sin estructura familiar -TIPO 2-12, el 77.3\% de promedio, si bien se observan substanciales diferencias entre el clero bajo ${ }^{13}$, un $55.6 \%$, y el clero medio ${ }^{14}$ y el alto $^{15}$, con el 79.1 y el $81.4 \%$, respectivamente. El contraste entre sus alcances anuales y el tamaño de las viviendas que les daban cobijo denotan de manera rotunda las profundas distancias que les alejaban en las vicisitudes de la vida cotidiana. Los capellanes conventuales, las medias raciones, los beneficios parroquiales y las prebendas catedralicias se debatían en mundos rotundamente separados -no siempre insalvables-, que respondían a su extracción social, patentizaban su grado de formación y cristalizaban en maneras de vivir manifiestamente diferenciales, e incluso, a veces, diametralmente opuestas.

El estatus profesional de los clérigos albergados estaba manifiestamente escorado hacia el clero medio y bajo -véase CUADRO II y GRÁFICO I-. El $30.6 \%$ de ellos eran medio racioneros parroquiales o catedralicios y capellanes de nulas o escasas rentas. Su aportación a los hogares que les acogían, 536 reales al año de promedio, suponía una breve cantidad que repercutía bastante poco, un $23.1 \%$, en las economías domésticas de la unidad doméstica en que se incluían. Eran predominantemente sus padres, el $100 \%$ de los casos registrados, quienes les albergaban. En el $36.4 \%$ de los casos no aportaban absolutamente nada al hogar. El clero bajo con vivienda independiente suponía sólo un $9.5 \%$ de los clérigos burgaleses y sus niveles de rentas frisaban los 1.400 reales

12 El método del Grupo de Cambridge y de P. Laslett para la clasificación de los hogares, aunque sujeto a múltiples críticas, controversias y mejoras, permite una sencilla tipificación de las estructuras domésticas y un funcional contraste con otras realidades locales, regionales o estatales. En esencia, como resumen, entendemos como TIPO 1 el propio de los «solitarios», TIPO 2 los «hogares sin estructura familiar», TIPO 3 los «hogares nucleares», TIPO 4 los «hogares ensanchados» y TIPO 5 los «hogares múltiples». Véase a este respecto R. TORRES SÁNCHEZ (1990) y F. J. SANZ DE LA HigUERA (2002a) en el Anexo Bibliográfico.

${ }^{13}$ Medios racioneros de la Catedral y de las parroquias y capellanes de conventos y de instituciones religiosas. Este proletariado eclesiástico de ínfimo nivel y escasas rentas presenta una idiosincrasia particular que permite, a mi juicio, diferenciarlo del resto de los clérigos de la ciudad. La mayoría de los autores embeben a este clero de rango bajo en el seno de los beneficiados parroquiales, denominándolos a todos con el susodicho epígrafe de «bajo clero» por contraste con el «alto clero» o catedralicio.

${ }^{14}$ Beneficiados parroquiales de Burgos, de otras localidades y de los barrios periféricos, capellanes del número y sochantres de la Catedral y capellanes y comendadores del Hospital del Rey y de Las Huelgas.

15 Dignidades, canónigos y racioneros de la Catedral y el comendador mayor del Hospital del Rey.

Hispania Sacra, LIX

120, julio-diciembre 2007, 563-594, ISSN: 0018-215-X 
CUADRO II. Clérigos independientes: Relaciones famliares y quehaceres profesionales

\begin{tabular}{|c|c|c|c|c|c|c|c|}
\hline & $\begin{array}{l}\text { Número } \\
\text { hogares }\end{array}$ & $\%$ & Padres & Tíos & Hermanos & Primos (1) & Tutor \\
\hline CLERO BAJO & 15 & 38,5 & 73,4 & 13,3 & 13,3 & & \\
\hline CLERO MEDIO & 16 & 41,1 & 43,7 & 12,5 & 31,2 & 12,6 & \\
\hline CLERO ALTO & 8 & 20,4 & 12,5 & 25,1 & 37,5 & 12,5 & 12,5 \\
\hline & $\begin{array}{l}\text { Aportación } \\
\text { clérigo }\end{array}$ & $\% \mathrm{AC}(2)$ & $\begin{array}{c}\text { Aportación } \\
\text { nula } \%\end{array}$ & $\begin{array}{c}\text { Alcance } \\
\text { anual (3) }\end{array}$ & $\%$ EP (4) & \multirow{4}{*}{\multicolumn{2}{|c|}{ Elaboración propia }} \\
\hline CLERO BAJO & 614 & 21,1 & 26,7 & 1398 & 9,5 & & \\
\hline CLERO MEDIO & 1973 & 33,5 & 12,5 & 2596 & 67,9 & & \\
\hline CLERO ALTO & 8836 & 55,7 & 0 & 8274 & 22,6 & & \\
\hline
\end{tabular}

(1) Primos, sobrinos, tíos...

(2) Porcentaje de aportación del clérigo a la economía del hogar.

(3) Alcance anual según la contabilidad del Catastro.

(4) Peso específico de las categorías profesionales del clero en el Catastro.

anuales. Es evidente que los clérigos dependientes de rango bajo se encontraban bajo la férula de sus parientes porque sus economías no les permitían sobrevivir en solitario - no deseaban sufrir en exceso el desamparo en la urbe- y se acogían a la solidaridad familiar como un mecanismo inexorable de defensa ante la incuria de los tiempos. La ciudad disponía de casas vacías o de múltiples estancias en alquiler que les hubiera permitido vivir por su cuenta pero era más cómodo o más viable aferrarse a los familiares más cercanos.

Clérigo y vivienda (Burgos, 1751)

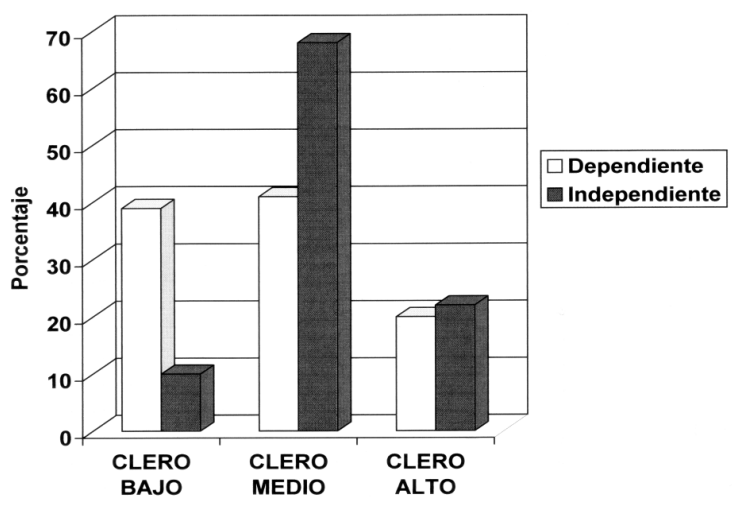

Hispania Sacra, LIX 120, julio-diciembre 2007, 563-594, ISSN: 0018-215-X 
El $55.6 \%$ de estos clérigos albergados se encuadraba en el clero medio -categoría profesional que en el contexto burgalés sumaba el $67.9 \%$ de sus efectivos-. Eran beneficiados parroquiales - de la ciudad o de localidades de la provincia-, capellanes del número de la Catedral o capellanes de Las Huelgas y del Hospital del Rey. Una cuarta parte de ellos se hallaba bajo la férula de los padres. Estos clérigos de rango medio se alojaban especialmente, el $65 \%$, junto a hermanas, hermanos o cuñados. Con otros parientes aparecen un residual $10 \%$. La aportación media que anualmente canalizaban hacia los hogares en que vivían, alrededor de 3.000 reales, generaba el $40 \%$ del dinero o del grano en ellos computables. Estos clérigos estaban en mejores condiciones económicas que los anteriormente citados -aunque aún se descubre un $10 \%$ sin ingresos de ningún tipo-, se apostaban en la senda de sus homólogos burgaleses independientes (2.600 reales/año) pero habían optado por permanecer en casa y compañía de sus familiares como una fórmula de manifiesta corresponsabilidad, como un ejercicio de ayuda mutua y acompañamiento en el marasmo de la urbe.

El $13.8 \%$ eran canónigos y racioneros de la Catedral, hermanados con su sangre fraterna o dados a la convivencia con tíos, primos, sobrinos y tutores, con quienes compartían, a partes iguales -su porcentaje de aportación al hogar era del $52.3 \%-$, unas contabilidades anuales elevadas y muy substanciales. Los 10.100 reales que canalizaban hacia los hogares en que se albergaban -similar a la de los canónigos en general (8.200 reales/año)- indican a todas luces las causas de su corresidencia. Merced a la suma de sus prebendas se vivía bastante mejor que por separado y se reducían de manera substancial el pago de los alquileres, de los salarios del personal contratado y de las viandas a ingerir, al compartir en la práctica un mismo edificio, el mismo servicio doméstico y la misma alimentación.

La óptica espacial, mediante el descubrimiento de en dónde se ubicaban las viviendas que les acogían, se detalla a través del CUADRO III. A la cabeza aparece la colación de Santa María la Mayor con el 33.3 \% de los hogares -el $25 \%$ intramuros, a los pies de la Catedral, y el $8.3 \%$ extramuros, en el arrabal de Vega, a la ribera sur del Arlanzón-. La mayoría de ellos, el 58.3 \%, eran beneficiados parroquiales de moderados ingresos -alrededor de los 2.000 reales /año-. El $25 \%$ eran canónigos catedralicios cuya aportación anual, por encima de los 10.000 reales, les hacía componentes esenciales de los hogares de acogida. Estos datos contrastan de una manera nítida con los 438 reales que al año percibían, de promedio, los clérigos dependientes de bajo rango hallados en esa colación. Desde una perspectiva global, nótese como el promedio de los alcances anuales y de la aportación de los clérigos dependientes eran muy elevados. El peso específico de estos eclesiásticos en las economías hogareñas que los albergaban basculaba entre el 37 y el $45 \%$.

Hispania Sacra, LIX

120, julio-diciembre 2007, 563-594, ISSN: 0018-215-X 


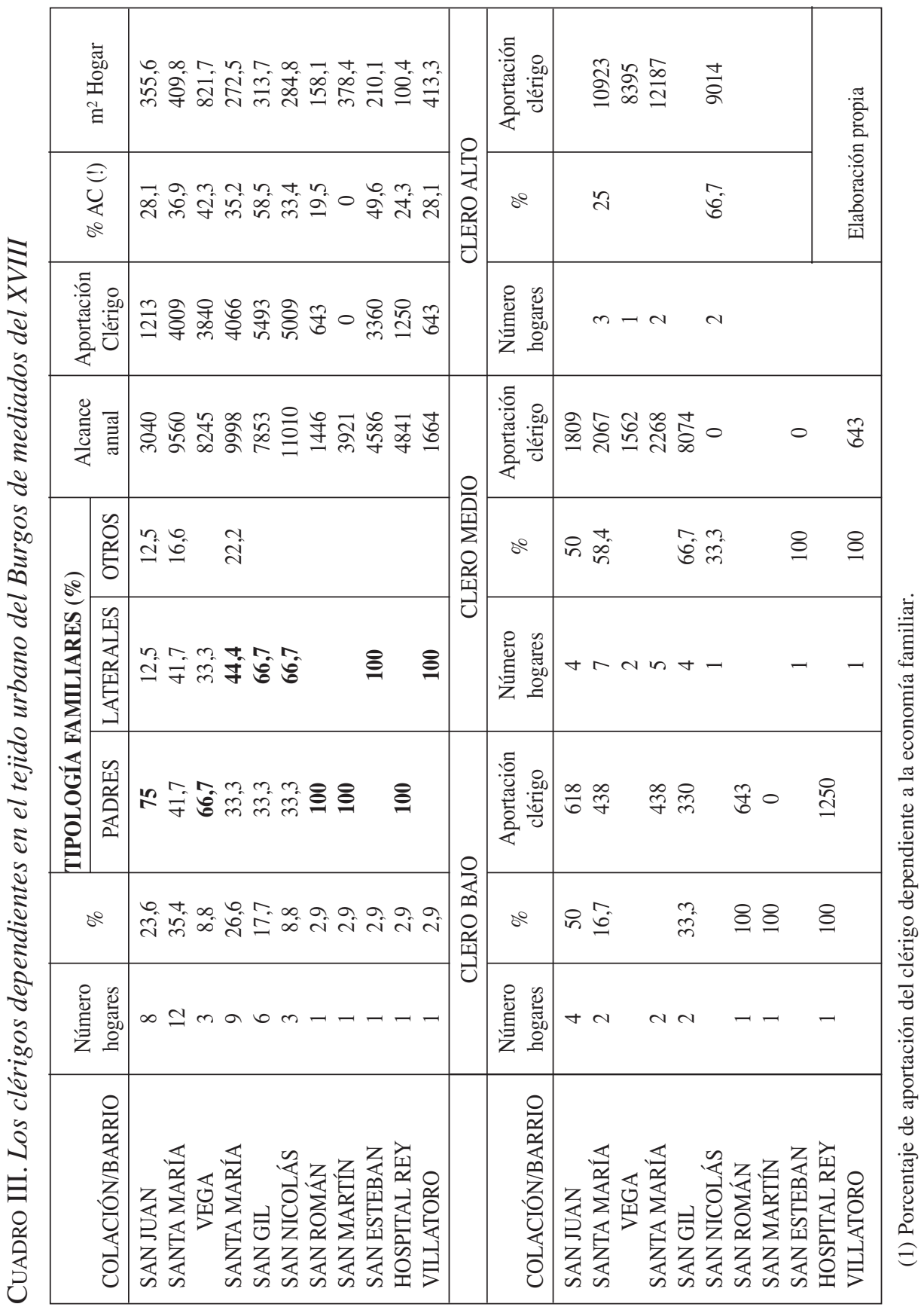

Hispania Sacra, LIX 120, julio-diciembre 2007, 563-594, ISSN: 0018-215-X 
La colación de San Juan y San Lesmes, en la que se encontraban ubicados el $22.2 \%$ de los hogares con clérigos dependientes, repartía al $50 \%$ su adscripción al clero de bajo y de medio rango. No aparece ningún canónigo. Las diferencias de ingresos entre unos y otros, 618 y 1809 reales, respectivamente, muestran de manera patente las sustanciales diferencias existentes entre los medios racioneros que habitaban junto a sus padres -en muchos casos no aportaban nada a la contabilidad familiar-y los beneficiados que residían en compañía de hermanos o tutores, individuos todos ellos adornados con suculentos ingresos anuales. El útil anual de los hogares, 3.000 reales, la aportación del clérigo, alrededor de los 1.200 reales, y el peso de su participación en la economía familiar, con un promedio del $28.1 \%$, nos muestra un importante contrapunto con respecto a la citada colación de Santa María.

San Gil, con el $16.6 \%$ de estos clérigos en sus calles, se escoraba, de forma manifiesta, hacia el clero medio -los beneficiados dependientes suponían el $66.7 \%$ de las ocurrencias, con una aportación, de promedio, superior a los 8.000 reales/añ - frente al restante $33.3 \%$, el del clero bajo, medios racioneros de escasa cualificación y modestas percepciones -330 reales de media al año-. En el otro extremo aparece la calle Tenebregrosa, la colación de San Nicolás (8.3\% de los casos de la muestra). De nuevo las cifras son contundentes y reiteran las apreciaciones anteriormente señaladas -que consolidan el sesgo probatorio de las hipótesis pergeñadas a priori-. Un beneficiado, que vivían con sus padres, no aportaba nada a la economía familiar, mientras que dos canónigos, corresidentes con hermanos o tíos eclesiásticos, llevaban a los talegos un promedio de 9.000 reales al año.

En las colaciones y barrios más periféricos -San Román, San Pedro de la Fuente y San Martín, San Esteban, Hospital del Rey, Las Huelgas y Villatorose ubicaban, como se observa en el CUADRO III, clérigos de baja y media estofa, de paupérrimos ingresos anuales -el $40 \%$ de ellos no aportaba nada a la familia que los acogía-.

Un recorrido exhaustivo por la tipología y los parámetros vitales de los familiares que albergaban a estos clérigos en sus casas posibilita traer a colación las causas, peculiaridades y vicisitudes de sus modestas o de sus opíparas existencias. Los comentarios que unos y otros hicieron a través del paño de lágrimas que, en ocasiones, fueron los memoriales del Catastro de Ensenada nos suministra, junto con los testamentos y los inventarios post-mortem que se ha conseguido recopilar, combustible histórico para un análisis crítico de por qué algunos eclesiásticos gozaban del favor de sus parientes y se surtían de casa, servicio doméstico mesa y cama, armarios y demás atrezzo hogareño de una manera casi gratuita.

Con parientes directos de carácter ascendente se albergaban el $63.8 \%$ de estos clérigos. En primera instancia, con ambos padres aún vivos, el $36.2 \%$. A 
mucha distancia se acogían con tíos -en su mayor parte también eclesiásticosun $16.7 \%$. Los hogares en que uno de los dos progenitores ya había fallecido sumaban el $11.1 \%-8.3 \%$ con el padre y $2.8 \%$ con la madre-. En un sesgo horizontal aparecen, con el $24.9 \%$ de las ocurrencias, hermanos (13.9\%), hermanas $(5.5 \%)$ y cuñados $(5.5 \%)$. En último término, el $11.1 \%$ se cobijaban en casa de parientes colaterales -con un tutor el $5.5 \%$ y con un sobrino o con un primo, con un $2.8 \%$, respectivamente-. Bajo la férula de una mujer aparece únicamente un $8.3 \%$ de tales clérigos que preferían aposentarse al lado de otro hombre en un porcentaje, $91.6 \%$, que no deja lugar a dudas sobre quién movía la batuta de la sociedad antiguo-regimental.

Desde una perspectiva socio-profesional se aprecia que los hogares en que se acomodaban eran predominantemente privilegiados. Al estamento nobiliar, ya fueran de sangre o hijodalgo, pertenecían el $55.6 \%$. Un $27.7 \%$ eran hogares comandados por otros eclesiásticos y únicamente un $16.7 \%$ se encuadraban entre los pecheros. Visto desde la óptica laboral, descuella la adscripción de los hogares con clérigos a su cargo en el mundo de la burocracia y los servicios públicos -el $49.9 \%$ eran funcionarios, comerciantes, gente de la sanidad...-, entre los eclesiásticos con vivienda independiente $-27.8 \%$ - y entre los labradores $-11.1 \%$. A uno de los segmentos más deprimidos de la sociedad, el de las hilanderas, y al más encumbrado, el de la nobleza rentista y dirigente de la ciudad, correspondían un somero, pero muy significativo por la coincidencia, $5.6 \%$, respectivamente.

La aspereza de la estadística, del esqueleto cuantitativo de la reconstrucción histórica, va a quedar compensada, a continuación, con la plasticidad y la viveza de las narraciones que nos han dejado en sus memoriales y testamentos estos clérigos y sus parientes más cercanos. Un repaso detallado a sus principales parámetros vitales, a sus vicisitudes y quehaceres cotidianos, añadirán músculo, tendones, piel y pelo, es decir, posibilitaran traer a colación cuerpos de carne y vestimentas a la revisión histórica. Una narración, a la postre, atractiva, elocuente y efectista, preñada de ejemplos y modelos de comportamiento que nos darán la clave para entender conductas y estrategias de cara a la ardua, y en ocasiones tremendamente difícil -incluso para muchos privilegiados-, tarea de sobrevivir en el Antiguo Régimen.

\section{III. ¿EN COMPAÑÍA O BAJO LA FÉRULA DE UN FAMILIAR?}

¿Cuál era la relación que los clérigos burgaleses sin vivienda independiente tenían con aquellos parientes junto a los que convivían? ¿Se aposentaban a la sombra de un familiar para huir del desamparo humano y la precariedad económica? ¿Se detectan otras fórmulas para explicar la corresidencia? ¿Cabe hablar 
de diferentes estrategias de convivencia según el volumen de los ingresos y el rango del clérigo?

En el CUADRO IV se hallan algunas de las respuestas a tales interrogantes.

CuAdRo IV. Parámetros vitales de los clérigos dependientes albergados junto a familiares cercanos en el Burgos de mediados del siglo XVIII

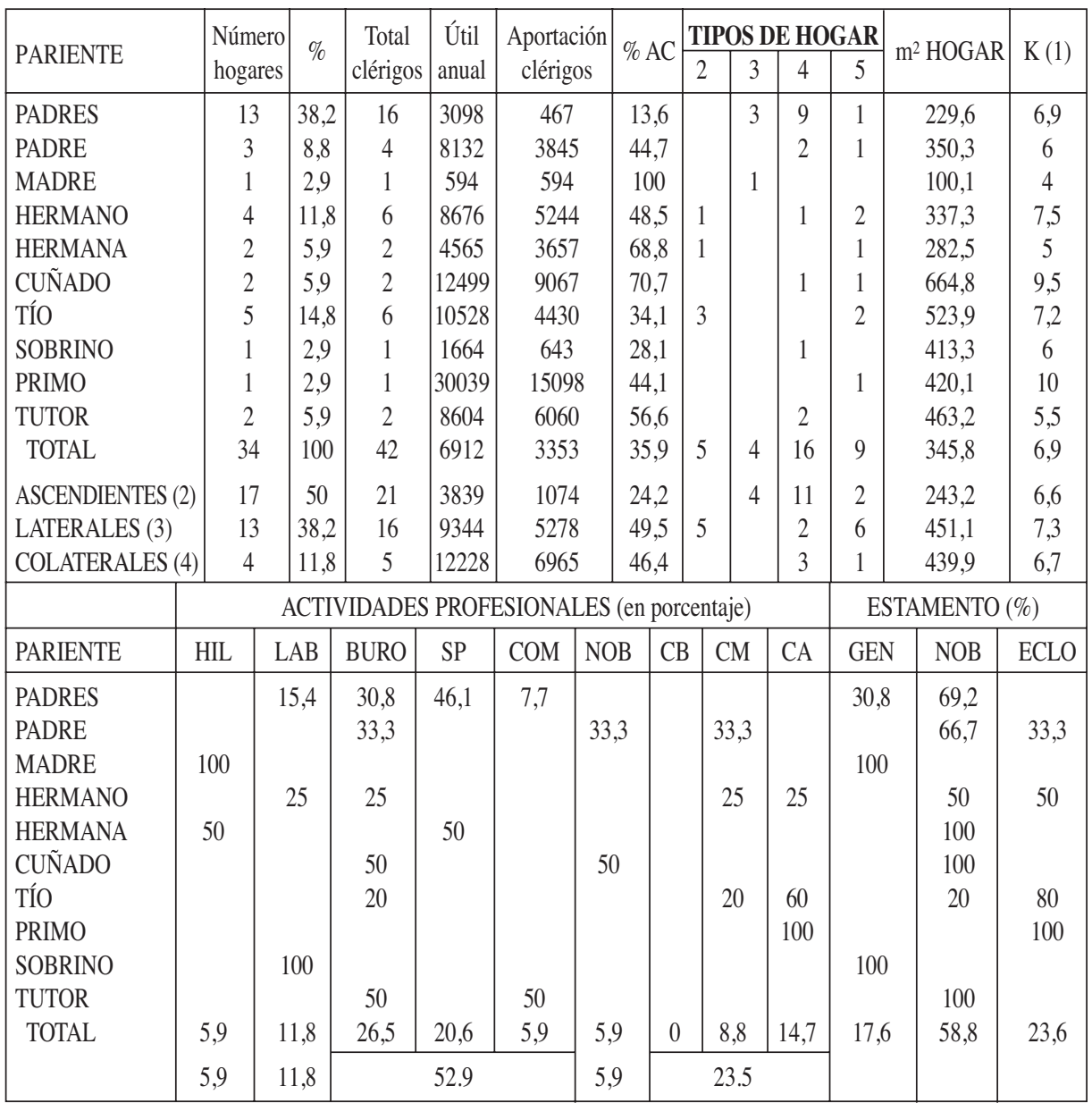

(1) K. Coeficiente de conversión vecinos/habitantes.

HIL: Hilanderas. LAB: Labradores. BURO: Burócratas. SP: Servicios Públicos. COM: Comerciantes. NOB: Nobleza dirigente. CB: Clero Bajo. CM: Clero Medio (Parroquias). CA: Clero Alto (Catedral).

(2) ASCENDIENTES. Padres, padre viudo y madre viuda.

(3) LATERALES: Hermano, hermana, cuñado/cuñada y tío.

(4) COLATERALES: Sobrino, primo o tutor

Elaboración propia

Hispania Sacra, LIX

120, julio-diciembre 2007, 563-594, ISSN: 0018-215-X 
Con ambos padres vivían -reitero- el $36.2 \%$ de estos clérigos. Con un padre viudo el $8.3 \%$ y con una madre viuda el $2.8 \%$. En resumen, con sus progenitores, casados o abocados a la viudedad, se acogían la mitad (47.3\%) de estos eclesiásticos.

Don Pedro de Hojas, de 32 años, vivía en «compañía de sus padres y hermanos». Sus quehaceres profesionales se repartían entre la atención a una capellanía en San Martín, propiedad de un tal don Pedro García de Valencia, a quien pagaba anualmente de renta 240 reales y de la que obtenía 300 ó 400 reales, y la mayordomía del convento de San Luis, de la Concepción franciscana, labor de la que se derivaban 800 reales/año. De los aproximadamente 1.200 reales que obtenía de ambos empleos salían los 400 reales que en alimentos daba a su padre, el pechero Miguel de Hojas, con quien vivía en la calle San Juan. Afirmó textualmente en su memorial que contaba con «la ayuda del hijo sacerdote» para sobrevivir. El progenitor se dedicada al alquiler de mulas -tenía 3 animales en los establos del entresuelo de la casa- De las actividades de ambos quedaban, después de pagados los imprescindibles desembolsos (alquiler de la vivienda, etc.), alrededor de 1.500 reales al año-promedio similar al de la ciudad en su conjunto-. Con ese útil se mantenía un hogar (3b)5 en el que Miguel, de 44 años en 1751, y su cónyuge compartían con sus tres hijos los $131.7 \mathrm{~m}^{2} \mathrm{de}$ suelos habitables, parte de los cuales eran ocupados por el clérigo, quien tenía partes de «sus rentas por separado». Los Hojas usufructuaban la mitad del entresuelo y la segunda vivienda ${ }^{16}$.

También «en compañía de sus padres», e igualmente en la calle San Juan, hallamos a don Nicolás Ruiz de Porras. A pesar de que su padre, don José Ruiz de Porras, era noble de sangre y trabajaba, a sus 67 años, como oficial de la correspondencia en la Administración General de Rentas -en la Delegación de Hacienda para entendernos-, donde obtenía unos ingresos brutos de 2.750 reales al año, don Nicolás era un mero medio racionero en la parroquial de San Lesmes (329 reales/año), sita en las inmediaciones del domicilio, y disfrutaba de un beneficio simple en Villar de las Yeguas (500 reales/año). Ambos quehaceres representan un $23 \%$ del alcance anual del hogar en que habitaba, cercano a los 3.000 reales. Su nivel de rentas duplicaba al promedio de Burgos, dato que

${ }^{16}$ En el otro piso, el «Quartto prinzipal», se acomodaba el sargento mayor del Regimiento de Milicias de Burgos, don Antonio Rebolledo y Blasón, persona de mayor alcurnia e ingresos que el mulero pero, a la postre, encerrados en un mismo inmueble, uno arriba y otro abajo. ADPB. Catastro. Memoriales, M, Libro 346, folio 344 y P, Libro 349, folio 571. Véase F. J. SANZ DE LA Higuera (2002a), pp. 165-211 y (2002b), pp. 335-360. En la misma órbita que los Hojas, don Hipólito Guerra, «sacerdote»-beneficiado en Santiago de la Capilla, con residencia independiente, ADPB, Catastro, H, Libro 349 , folio 345-, abonaba la renta de la casa de sus padres, chocolateros y posaderos, quienes afirmaban taxativamente que «sino fuera por el hijo sacerdote anduvieran a pedir Limosna». ADPB, Catastro, P, Libro 347, folio 98. 
nos permite aventurar una existencia lejana tanto de las paupérrimas y lacerantes miserias de los más desafortunados como del boato y la magnificencia de la clase dirigente de la ciudad ${ }^{17}$. El inventario que se efectúa de sus bienes en el momento de su fallecimiento corrobora este aserto. Con poco más de 20.000 reales, por debajo de esa cifra se hallaban prácticamente el $60 \%$ de los IPM recopilados para el Burgos de mediados del XVIII ${ }^{18}$. El matrimonio conformado por don Nicolás y doña María Jacinta Zacona tenía bajo su férula al citado clérigo ${ }^{19}$ y a dos sirvientes contratados para la atención doméstica -se trata, por tanto, de un hogar (4c)6, un hogar burgués de esa época ${ }^{20}$. Todos ellos se debatían habitualmente sobre $122 \mathrm{~m}^{2} \mathrm{en}$ el seno de un edificio por el que pagaban al año 400 reales y que ocupaban en solitario, sin las molestias de ningún otro hogar subiendo por las mismas escaleras ${ }^{21}$.

Don Manuel Ruiz de Velasco era, a sus 55 años, padre de un «sacerdote sin Rentas», al que se veía obligado a cobijar, alimentar y mantener dada la precariedad de los tiempos ${ }^{22}$. Por 420 reales al año tenía alquilado un inmueble, en la susodicha calle San Juan, con $198.4 \mathrm{~m}^{2}$ de suelos habitables. En sus estancias se alojaban ocho personas, conformando un hogar (4a)8, de singular estructura ${ }^{23}$. Don Manuel sacaba adelante a su dilataba y compleja familia merced a un curioso pluriempleo que le llevaba desde la administración del alfolí de la sal (2.200 reales/año) hasta la administración de las alcabalas (580 reales) y los vi-

17 F. J. SANZ DE LA HigueRA (2002a) -véase anexo bibliográfico-.

18 AHPB. PN. José Julián Villar. Legajo 7162 (1758), folios 298-311.

${ }^{19}$ Además del clérigo residente en casa, don José era padre de don Francisco Antonio, beneficiado simple servidero en Trujillo y de «quartilla» en Sargentes de Lora, a la par que profesor teólogo en la Universidad de Valladolid y de don Joaquín y don José Felipe, contador principal del ejército de principado de Cataluña, de 42 años, y cadete en el regimiento de dragones de Sagunto, de 23 años, respectivamente. Todos los hijos que aparecen en su memorial catastral eran varones, dos clérigos y dos dedicados a asuntos castrenses. Es muy probable que de haber tenido hijas alguna, o todas, hubieran sido derivadas a algún convento o monasterio.

${ }^{20}$ R. TORRES SÁnChEZ: «El hogar del burgués», en L. M. EnCiso Recio: La burguesía en España, 1996, Valladolid, vol. I, pp. 253-268.

${ }^{21}$ ADPB. Catastro, Memoriales, J, Libro 345, folio 755 y N, Libro 349, folio 480.

22 AHPB. PN. José Guadilla. Legajo 7129 (21 de mayo de 1764), folios 115-118 y (18 de septiembre de 1769), folios 526-527. Con su hijo, don Julián, se gastó «en estudios maiores, grados y oposiciones que a echo a prevendas en esta Sta Iglesia y en la colejial de Birbiesca» (sic) los 4.272 reales, «y aún mисho más», que en diferentes alhajas y mandas trajo al tiempo del matrimonio su segunda mujer. En 1764, a pesar de sus esfuerzos, no había llegado más que a «Capellán en la Parroquia de Sn Lorenzo», empleo de escasa notoriedad y cortas rentas. En 1769 era, empero «Cura rector en Sn Salbador de Sepúlbeda». Ya había conseguido marcharse de casa y de Burgos. Loque le correspondía de los tres años y medio que vivió su madre estaba ya suficientemente gastado, «lo que tiene recivido mucho más (...) sin cargarle la manutenzión de sus estudios».

${ }^{23}$ Junto al matrimonio aparecen, en casa y compañía, el citado clérigo, cuatro hijas e hijos más y su madre, viuda, mayor de 70 años e «imposibilitada». No tenían servicio doméstico contratado. Era también el único hogar del edificio. ADPB. Catastro, Memoriales, M, Libro 346, folio 557.

Hispania Sacra, LIX

120, julio-diciembre 2007, 563-594, ISSN: 0018-215-X 
drios (220 reales). A ello se añadían 33 reales que le redituaban algunas propiedades sitas en otras localidades burgalesas ${ }^{24}$. Un «Capellán sin rentas» aparece, por otra parte, en casa de Simón Temiño, un hidalgo de 58 años, que, en compañía de $\mathrm{M}^{\mathrm{a}}$ Nieves Gete, explotaba una casa mesón, en Cantarranas la mayor, que les dejaba anualmente 2.750 reales de útil25. Un desembolso de 650 reales les permitía, sobre $540 \mathrm{~m}^{2}$, usufructuar un edificio en solitario, en una de cuyas estancias, abatido por su incierto futuro, se resguardaba el clérigo citado. El hogar, un (5c)7 de carácter múltiple, pone una nota de color a estos retratos familiares por la complejidad de su estructura ${ }^{26}$.

En la calle Tenebregosa y en San Martín descubrimos otros dos casos de clérigos sin renta, y por tanto con una aportación nula al presupuesto familiar, cobijados bajo la férula de sus progenitores y con escasas perspectivas de mejorar sus niveles de renta. Sus quehaceres profesionales y sus vidas cotidianas diferían substancialmente. En primera instancia descubrimos a un burócrata ${ }^{27}$ de modestos recursos, don José Sainz de la Peña, noble de 57 años, uno de cuyos hijos era «clérigo de menores, beneficiado de préstamo simple en la ermita de Las Herinuelas», actividad que no le reportaba rendimiento económico ${ }^{28}$. El hogar, un (4c)7, soportaba, sobre aproximadamente $140 \mathrm{~m}^{2}$, al matrimonio, dos hijos de 24 y 22 años, respectivamente, -«estudiantes a costa del padre»-, una hija de 18 y una cuñada, hermana de doña Dionisia de Trevilleja, su cónyuge, «imposibilitada» y acogida de limosna ${ }^{29}$. En segundo término, Francisco Díez,

\footnotetext{
${ }^{24}$ Como se va a señalar en otras ocasiones, un rastreo sistemático de las Respuestas Particulares de la provincia de Burgos y de las limítrofes (Logroño, Santander, Palencia, Valladolid, Ávila, ...) ha permitido recuperar las propiedades y las rentas de los vecinos de la ciudad de Burgos a mediados del XVIII -a ello han colaborado también los testamentos y los IPM-. No se van a detallar las referencias puntuales de archivo por razones de espacio físico en el desarrollo de este artículo.

${ }^{25}$ En un pueblo cercano obtenía 102 reales al año de rentas. Ser familiar de un clérigo daba carácter. Don Esteban Pascual, beneficiado en San Lesmes, que años después cobijó a un sobrino también clérigo en su casa, lo afirmó rotundamente en su memorial catastral al advertirnos que vivía con una hermana viuda a la cual trataba con «la decencia correspondiente a la hermana de un sacerdote». En 1751, el sobrino, hijo de la viuda, era aún «estudiante» ADPB. Catastro. Memoriales, E, Libro 349, folio 47.

${ }^{26} \mathrm{El}$ hogar estaba conformado por el matrimonio, tres hijos -otros dos estaban en ausentes, «mantenidos por un tío»- y un criado y una criada de mesón, hermanos. Ambos núcleos familiares generan un hogar múltiple, en este caso por razones laborales. Ibídem, S, Libro 347, folio 369. En su IPM se señala que era su expreso deseo «no se les quenten los gastos de sus estudios y acomodo; ni a los tres primeros los alimentos y gastos que han ocasionado desde que gozan su Capellanía y Prevendas en atención a que los emolumentos de ellos los hemos percivido desde que las gozan». AHPB. PN. Bernardo Alonso de Illera. Legajo 7191 (18 de octubre de 1772), folios 174-175.

${ }^{27}$ Notario mayor del oficio de obras pías del tribunal eclesiástico de Burgos y su Arzobispado y oficial mayor del partido de Lara y Candemuñó.

${ }_{28}$ Véase J. Bravo Lozano: «Cura rico, cura pobre...», Op. Cit., pp. 129-139.

${ }^{29} \mathrm{El}$ hogar tenía igualmente el edificio en exclusiva. ADPB. Catastro, Memoriales, J, Libro 345, folios 699-700.
} 
pechero, labrador y ganadero ${ }^{30}$, era padre de un joven de 25 años, «estudiante $y$ clérigo de menores y beneficiado de quartilla en el lugar de Hurones, a quien mantengo por no valer nada el benefizio». Las ocho personas que componían el hogar, (4c)8, desplegaban su existencia en dos casas anexas que, en conjunto, ponían a su disposición, y en exclusiva, $378 \mathrm{~m}^{2}$, inmuebles típicamente campe$\operatorname{sinos}^{31}$.

Don Manuel de la Concha, don Diego Arciniega, don Blas Rangel, Andrés García y Martín Ibeas Vivanco tenían en común, a pesar de sus hondas diferencias socio-económicas, albergar en sus casas a un hijo que ganaba una modesta prebenda como medio racionero en alguna de las parroquias de la ciudad o de otras localidades. Don Manuel de la Concha, hidalgo y oficial de la notaría mayor de Cruzada, era padre de Miguel, de 29 años, «presbitero y medio razionero en San Gil». Al primero se le calculan 3.000 reales al año, al segundo 700, es decir, un $18.9 \%$ de los ingresos. Descontados los gastos habituales, la economía doméstica se debatía lánguidamente entre la precariedad y cierta confortable cotidianeidad, sobre los casi $500 \mathrm{~m}^{2}$ que la familia, otro ensanchado hogar (4c)7, disfrutaba en la primera vivienda de un edificio de la plaza Margarita ${ }^{32}$. Su IPM, en que se computan bienes por valor de 12.376 reales, es una magnífica herramienta para evaluar la cortedad de sus posibles ${ }^{33}$. Muestra de su entrañable afecto es que don Manuel determinó que don Feliciano fuera quien eligiera la sepultura en que yacería una vez muerto -en San Gil, como no podía ser de otra manera, por múltiples motivos que señalaremos convenientemente ${ }^{34}-$. En un estatus similar se encontraba el boticario Diego de Arciniega, de 56 años, noble de sangre, quien en su hogar (4c)9 incluía a un hijo de 23, «beneficiado de media razión en la villa de Palenzuela» a mediados de $1751^{35}$. Las circunstancias económicas de unos y otros eran bastante inciertas. Don Diego afirmaba que «no hay seguridad de vender el consumo de medicinas» y añadía «hazien-

\footnotetext{
30 Véase F. J. SANZ DE LA HigueRA (2006): «Producción, venta y consumo de lácteos...».

${ }^{31}$ Las dos casas eran propiedad suya y ningún otro hogar alteraba su intimidad. ADPB. Catastro, Memoriales, F, Libro 344, folios 746-747.

32 En el edificio se desplegaban dos hogares, dado que en el entresuelo estaba alojado un oficial de pluma de la Dirección General de Rentas. Ibídem, M, Libro 346, folio 350.

33 AHPB. PN. Nicolás Martínez Vivanco. Legajo 7150 (1779), folios 689-699. Sus últimas voluntades en Ibídem (1770), folio 565. El testamento consta sólo de un raquítico folio. De los 533 testamentos que para los vecinos de Burgos a mediados del Setecientos se han recopilado el $0.4 \%$ únicamente tienen una página, un $21.6 \%$ se despliegan en las dos caras de un folio, el $59.6 \%$ en 1 ? ó 2 folios y con más de 2 folios suponen un $18.4 \%$.

${ }^{34}$ Su hijo era en 1770, el «Cura y Beneficiado más antiguo en ella», donde además don Manuel era «parroquiano». Véase C. Alonso DE PORREs: Las parroquias en la ciudad de Burgos, Burgos, 1981.

35 Don Diego Dámaso de Arciniega, «Presbítero Capellán en el Real Monasterio de las Huelgas» había recibido, a la muerte de su padre (1760), las legítimas paterna y materna, «los Vienes, Dinero y demás efectos» que legítimamente le correspondían. AHPB. PN. Joaquín Noguerado. Legajo 7105/2 (26 de diciembre de 1760), folios 469-471.
}

Hispania Sacra, LIX

120, julio-diciembre 2007, 563-594, ISSN: 0018-215-X 
do una prudente Regulación, porque a punto fijo no es posible saber lo que reditúa, ni ello puede aber seguridad alguna por depender del consumo de Medicinas, y menos en los tiempos presentes por haberse puesto barias Boticas en los contornos de la Ciudad» ${ }^{36}$.

Blas Rangel constituye por la singularidad de la documentación que se ha conseguido recopilar un caso a destacar de manera detallada. Su hijo, Ángel, era «diácono beneficiado en la parroquia de Santa María La Blanca y San Andrés» y sacristán mayor de ella. En ambos empleos obtenía una cifra cercana a los 650 reales al año -aportaba a la economía familiar un $20 \%$ de los ingresos-. Blas Rangel y Agustina Barriuso eran labradores y «después de la labranza el tiempo que le sobra se ejercita en portear piedra y arena para diferentes obras». El alcance anual del hogar, alrededor de los 1.500 reales, alimentaba y mantenía un hogar (4c) 737 , ubicado en una casa de alquiler en el barrio de San Román. El espacio habitable frisaba los $160 \mathrm{~m}^{2}$, a lo que se añadía «un descolgadero con un horno de ocho varas en quadro», un corral de una fanega y un herrén de mismo tamaño. Blas Rangel al fallecer dejó propiedades evaluadas en 34.314 reales $^{38}$. Era tal el afecto y la devoción de Blas por su hijo, confidente y amigo siempre del padre, que lo nombró en sus últimas voluntades su testamentario, heredero y además fue su «voluntad mejorar como mejoro en el tercio y remanente del quinto de todos mis bienes y hacienda a Dn Ángel (...) en atención a el Cariño que le he tenido y tengo»39.

Entre los pecheros se hallaban los citados Andrés García y Martín Ibeas Temiño. El primero, de 78 años, era ayudante del correo mayor. Su hijo Manuel, de 25 años, estaba «ordenado de evangelio a título de un beneficio de cámara pero no goza de emolumentos». En realidad, lo descubrimos en una media ración de San Esteban, donde percibía 570 reales al año, cantidad que supone el $36 \%$ de los ingresos de su hogar, un (3b)4 nuclear, marcado por la escasez -se declaró «sin bienes»- y la estrechez $-99.2 \mathrm{~m}^{2}$ era el espacio habitable que obte-

${ }^{36}$ En el inmueble se recogían de forma simultánea tres hogares. El del boticario y el de una lavandera viuda y un jornalero, de escasos alcances y miserable existencia. ADPB. Catastro, Memoriales, D, Libro 344, folio 699. Véase F. J. SANZ DE LA HigUERA (2002a) -anexo bibliográfico-.

${ }^{37}$ En la órbita del matrimonio se encontraban el citado clérigo, tres nietos, de corta edad, acogidos de limosna, y dos criados para la labranza. Este hogar campesino ocupaba en solitario el inmueble que Blas y Agustina tenían alquilado. Ibídem, B, Libro 344, folios 470-472 y A, Libro 348, folio 42. Véase F. J. SANZ DE LA HigueRA (2005) -anexo bibliográfico-.

38 AHPB. PN. Ángel Arnaiz. Legajo 7165(1758), folios 186-201.

39 Ibídem, Ángel Arnaiz. Legajo 7165 (17 de diciembre de 1758), folios 227-228. En el testamento de 1757 se señala que «para sus estudios y al tiempo que los tres últimos contrajeron matrimonio [se les dieron] diferentes porciones de dinero, granos y bienes de entrecasa, de cuio importe no hago memoria cierta, ni ai ynstrumento que lo Califique». Contrasta abiertamente la minuciosidad de unos y la flexibilidad de otros a la hora de computar las inversiones en su progenie, como se ha demostrado en varias ocasiones. Ibídem, Andrés Miguel Varona. Legajo 7165 (7 de mayo de 1757), folios 32-33. 
nían por el pago de 121 reales de alquiler anual en la paupérrima Cantarranillas-40. Por su parte, Ibeas Temiño era barbero. Los parámetros económicos que envolvían sus existencias eran fiel reflejo del modesto devenir de un hogar nuclear, (3b)4, de cortos alcance, 662 reales de útil anual, y escuálido espacio para la convivencia, $25.2 \mathrm{~m}^{2}$. El primero de sus hijos, de 25 años, era «sacerdote $y$ beneficiado de media razión en San Lesmes» (167 reales/año). El segundo, de 23 años, «clérigo de prima, graduado de teología y opositor a beneficios». Ambos permanecían en casa y compañía de sus padres, suspirando por un porvenir exitoso y lejano del paupérrimo caldo de cultivo en que se habían criado. La familia y el clientelismo eran estribos indispensables para auparse desde la carencia hasta la comodidad que brindaba un quehacer -o múltiples quehaceres- de orden eclesiástico ${ }^{41}$.

El contraste entre estos hogares más desafortunados y el que albergaba a don Francisco Antonio Sáenz de Viniegra constituye un punto de inflexión socio-económico de notable envergadura. Sus padres, don Francisco Sáenz de Viniegra y doña Rosa de Fábrega, de 50 y 42 años de edad, respectivamente, dispusieron a lo largo de su existencia de una amplia espacio residencial, alrededor de $340 \mathrm{~m}^{2}$, en el que cobijar, en la elitista calle La Paloma, un nutrido grupo de personas, un hogar (4c)1242, mantenido con un nivel de rentas holgado -el alcance anual de su empresa era superior a los 10.000 reales-, producto de sus quehaceres como mercaderes de paños y sedas y un suculento IPM, que sobrepasaba el medio millón de reales ${ }^{43}$. El futuro profesional estaba vinculado indisolublemente al bienestar y a la herencia paterno/ materna. La fortuna era un factor decisorio en la consolidación del status. Don Francisco Antonio era, a sus 22 años (1751), medio racionero de la Catedral y capellán de la Concepción, actividades en las que, junto a algunas modestas rentas procedentes de la provincia, obtenía, poco más o menos, 877 reales, cantidad que no suponía más de un $7 \%$ de ingresos en la economía familiar. Con el paso del tiempo alcanzaría importantes cuotas de poder y de influencia en el Cabildo burgalés e incluso en otras instituciones eclesiásticas de la geografía española ${ }^{44}$.

40 ADPB. Catastro, Memoriales, A, Libro 344, folio 256 y M, Libro 349, folio 460.

${ }^{41}$ En el edificio convivían dos hogares. Ibídem, M, Libro 346, folio 469. Véanse los análisis de J. BRAVO LOZANO: «Cura rico/cura pobre...», Op. Cit., pp. 131-132.

${ }_{42}$ El matrimonio tenía bajo su férula 6 hijos y una hija. El servicio doméstico estaba constituido por dos criadas y un criado para la tienda. Ibídem, F, Libro 344, folio 778 y F, Libro 349, folio 179.

43 AHPB. PN. Francisco de Villafranca. Legajo 7098/1 (1768), folios 17-50.

44 Ibídem, Francisco de Villafranca. Legajo 7094 (28 de abril de 1761), folios 600-603. «Declaramos que a Dn Franzisco Saez de Viniegra, nro hijo, Prevendado en la Sta Iglesia Metropolitana de esta Ciudad, fiscal Jral ecc co de ella y su Arzobispado (...) les hemos asistido de todo lo nezesario para sus estudios maiores, Cursos, Grados, Oposizión que hizo dho Dn Francisco a la Doctoral de Palenzia, viaje a Madrid y demás, manteniéndolos en sus estanzias en esta Ciudad y en nra Casa, en que hemos suplido Crezidas porziones y en bestirlos y Compra de Libros, que uno y otro con separazión y distin-

Hispania Sacra, LIX

120, julio-diciembre 2007, 563-594, ISSN: 0018-215-X 
Con un padre viudo convivían tres clérigos, un $8.8 \%$ de los eclesiásticos dependientes residentes en Burgos. El perfil que se entresaca de los documentos que para ellos han sido recopilados nos acerca a realidades diferentes de las anunciadas en el entreacto anterior. Descuella don Feliciano Fernández Vivanco, «presbítero beneficiado en la parrochial de Santa María de La Blanca» y miembro de la Congregación de La Real y de otras instituciones ${ }^{45}$. Vivía en los entresuelos del edificio alquilado por su padre, el licenciado don Lucas Fernández Bedón, noble de sangre y abogado en Burgos y en la villa de Cascajares de la Bureba. De sus múltiples quehaceres profesionales obtenía unos ingresos cercanos a los 1.500 reales, cantidad que supone un $48.7 \%$ de las cantidades llegadas al hogar, un (4b)5 en que el abogado, el clérigo, dos criadas y una nieta del burócrata, se desenvolvían habitualmente sobre $36 \mathrm{~m}^{2}$ de suelos habitables ${ }^{46}$. El padre confió siempre en el clérigo, «nro mui amado hijo» ${ }^{47}$. Empero don Antonio Carrillo y Acuña, canónigo en la Catedral, hijo del regidor perpetuo don Juan Manuel Carrillo, y don Marcos y don Santiago Río Pando, hijos del viudo y entrado a beneficiado de San Cosme don Ildefonso Río Pando, difieren de este sesgo y presentan algunas novedades muy significativas.

Don Ildefonso comandaba un hogar (4c)5 en el que él, viudo ${ }^{48}$, tutoraba el porvenir de sus tres hijos y de una criada. La vivienda en que se cobijaban era propiedad exclusivamente suya ${ }^{49}$, sita en la calle La Yedra, en Santa Dorotea.

zión resulta del libro de quenta y razón que llebamos de lo que Gastamos y entregamos a estos y demás nros hijos». En 1749 elevó al Cabildo un memorial ha través del cual conocemos que había «cursado dos años en la facultad de Leyes en la Universidad de Valladolid» y deseaba «continuar en sus estudios». ACC. Actas capitulares. Registro 106. Cabildo de 13 de octubre de 1749, folio 48v.

${ }^{45}$ Se repite sistemáticamente la imagen de un «proletariado pluricapellán» que ha señalado, tan acertadamente, J. Bravo LoZANo, Op. Cit., (1994), pp. 129.

${ }^{46} \mathrm{El}$ inmueble estaba repartido entre cuatro hogares diferentes (un médico, un mercader, un mesonero y un abogado). ADPB. Catastro, Memoriales, L, Libro 345, folio 953.

${ }^{47}$ AHPB. PN. José Maestre. Legajo 7064 (26 de septiembre de 1749), folios 125-126. «...que teniendo presente los muchos socorros y antizipaziones que a nra súplica nos a echo el referido nro mui amado hijo Dn Pheliziano Manuel Frz de Bibanco que abrán ynportado por la parte que menos más de Setezientos Ducados Vellón, los que se an conbertido en común Benefizio de la familia por no aberme allado con aquella dispozión que anteriormente para mantenerme en el ministerio de la Abogazía por cuias razones que son ziertas y mui seguras y por ntales las confieso en este peligro ynstante de mi vida». Se mejoró con el tercio y remanente del quinto de todos los bienes al susodicho don Feliciano (lo cual suponía más de 3.000 ducados, heredados de doña María Bravo, su suegra).

${ }_{48}$ AHPB. PN. Jacinto Álvarez. Legajo 7119/2 (1 de septiembre de 1766), folios 254-256. «...declaro que quando Casé con la Expresada Da Jpha Senar y Alvarado, Viuda del Liz do dn Manuel Jayme Correxidor que fue de la Villa de Villarcaio (...) traxo dha $D^{a}$ Jpha a da María Anttonia, Dn Anttonio Lucio y $D^{a}$ Jha Quitteria Jayme, sus tres hijos lexíttimos (...) muertto en suma Estrechez».

49 Dos cómputos, complementarios, nos ilustran sobre este asunto. Únicamente el $2.9 \%$ de los vecinos de Burgos a mediados del XVIII era propietario eminente de su vivienda. Si lo contemplamos desde la perspectiva puntual de los clérigos, diremos que don Ildefonso formaba parte de una élite de presbíteros, el $6.3 \%$ de ellos, propietarios del inmueble en que vivían, porcentajes que avalan la importancia del comentario que se inserta en este apartado. 
Con 6.6 metros de altura, la estructura del inmueble era la habitual en muchas casas de Burgos. En la planta baja o entresuelo se descubría un portal, una caballeriza pequeña y una despensa. En el piso primero o principal 3 ó 4 estancias o «quartos». Sobre todo ello aparecían 3 desvanes completamente «inhabitables». Los suelos útiles para la convivencia suponían aproximadamente $188 \mathrm{~m}^{2}$, a lo que se debe añadir el disfrute de un jardín de 6 celemines con varios árboles. El primogénito, Felipe, era «teniente de granaderos de milicias». Su situación era bastante complicada. Su padre señala en el memorial catastral que lo mantenía «desde hace tres años por encontrarse sin sueldo ni remuneración desde la Retirada general de la tropa en Italia». Don Marcos afirmó que vivía con su padre. Era beneficiado en Salguero de Juarros, quehacer arrendado a otro clérigo que le sufragaba 100 reales al año. Corría de su cuenta «todo lo concerniente a gastos de apeos de las tierras beneficiales y abrir arroyos-«por estar mandado por el auto de la última visita»-. Era tan escasa dicha renta que se ayudaban mutuamente a soportar las penurias. Advirtió en su memorial que «contribuye a su padre (...) en cuia casa vivo para aiuda de la manutención, que no pudiera ser sin esta unión». Santiago era beneficiado en San Pedro y San Felices. No esta ordenado de prima tonsura. Entre todos ellos lograban reunir 3.000 reales de útil al año, de los cuales un $45 \%$ provenía de los hijos clérigos $^{50}$. Don Ildefonso, en sus testamentos de 1750 y 1766, señaló, por una parte, que por el fallecimiento de su cónyuge «me dediqué al estudio y me hize como lo soy presbítero capellán»y, por otra, «Respectto mis Cortos vienes dejo a la elezión de mis hijos y herederos hagan por mí alma los demás Subfragios que les pareciere». También se acordó de «los Gastos que con ellos e echo en su acomodo y alimentarlos [que] an sido yguales» ${ }^{51}$.

El modo de vida más confortable y holgado, por contraste con los enunciados, era el protagonizado por don Antonio y don Juan Carrillo. Tanto las dimensiones de la vivienda, con $827 \mathrm{~m}^{2}$ de suelos habitables, como sus niveles de renta y fortuna, con un alcance anual cercano a los 20.000 reales -en el que el hijo clérigo aportaba un 40.1 \%- y un IPM, don Juan Manuel, superior a los 45.000 reales $^{52}$, respectivamente, delatan su pertenencia a la aristocracia media de la ciudad, es decir, la de los caballeros regidores del Concejo, como hijodalgo, y la de las canonjías de la Catedral. Don Antonio era, en 1751, «canónigo coadjutor en la Santa Iglesia Metropolitana», donde obtenía ingresos por un montante ligeramente inferior a los 8.500 reales. Tan elevada cantidad no le había pre-

\footnotetext{
${ }^{50}$ Véase F. J. SANZ DE LA Higuera (2002a). ADPB. Catastro, Memoriales, I, Libro 349, folio 348 y M, Libro 349, folio 479.

${ }^{51}$ AHPB. PN. Francisco de Villafranca. Legajo 7089 (6 de noviembre de 1750), folio 305-306 y Jacinto Álvarez. Legajo 7119/2 (1 de septiembre de 1766), folios 254-256.

52 AHPB. PN. Jacinto del Río. Legajo 7054/3 (1756), folios 362-374. ADPB. Catastro, Memoriales, J, Libro 345, folios 353-354 y A, Libro 348, folio 36.
}

Hispania Sacra, LIX

120, julio-diciembre 2007, 563-594, ISSN: 0018-215-X 
dispuesto a abandonar el hogar, dado que vivía «en compañía de su padre don Juan Manuel Carrillo». El componente fundamental de sus ingresos eran «las Rentas y efectos del Mayorazgo que poseo situados en distintos lugares de esta Provincia donde se dará Razón puntual quando llegue el caso de la operación en ellos» ${ }^{53}$. Se vislumbra, por tanto, una alianza funcional entre lo eclesiástico y lo nobiliar que sin ser espectacular si nos anuncia una fórmula extrema de convivencia entre un eclesiástico y quien le daba cobijo, basada, en esta ocasión, en una relativa igualdad o equilibrio, circunstancia minoritaria pero propia de las clases más encumbradas.

Por el contrario, don Pablo Antonio de Apéstegui escenifica, por la estrechez material y económica en que se debatían los miembros del hogar en que se inserta, lo paupérrimo y lo degradado. Este clérigo era acólito en la capilla de la Purificación y criado de los escribanos del número, empleos en los que obtenía aproximadamente 660 reales al año. Vivía «en compañía de su madre y dos hermanas» en el seno de un hogar nuclear, de escaso tamaño y reducida cualificación profesional -todas ellas se dedicaban a la hilatura y la mendicidad-54.

Con un familiar directo de carácter ascendente (tío) o de índole horizontal (hermano, hermana, cuñada o cuñado) cohabitaban el $41.6 \%$ de los clérigos dependientes objeto de análisis. El $16.7 \%$ eran prebendados que se hallaban bajo la férula de otro eclesiástico, un tío que les acogía, como era usual en la época, en su casa y compañía con objeto de paliar sus carencias familiares de origen y darles, a la postre, un estado preñado de futuro ${ }^{55}$. Con excepción de Martín Quintano, residente en los entresuelos del inmueble alquilado, en San Cosme, por don Manuel Fernández Quintano, procurador del número, individuo laico integrado en el estamento noble, los demás eran también miembros de la carrera eclesiástica.

53 En una muy avanzada fase de redacción se encuentra «El Catastrazo de Ensenada», documento en que se analizan las consecuencias que hubiera tenido en las labores de reconstrucción histórica la aceptación de las propuestas del marqués de Espinardo en lo tocante a realizar memoriales de patrimonio no por bandos sino por personas (hogares) y el cómputo del útil agrario y ganadero merced al concurso de las tazmías. Véase C. CAMARERo Bullón: «La producción agraria en el siglo XVIII. El Catastro de Ensenada y las Certificaciones de diezmos como fuentes para el estudio de la producción y de los rendimientos agrícolas. Análisis de un caso real: Gumiel de Hizán, 1748-1752», Estudios Geográficos, núm. 174, Madrid (1984), pp. 81-107 y «Las detracciones sobre la economía agraria y el endeudamiento del pequeño campesino en el siglo XVIII: aplicación a un Concejo castellano», Agricultura y Sociedad, núm. 33, Madrid (1984), pp. 197-254.

${ }^{54}$ ADPB. Catastro, Memoriales, P, Libro 349, folio 574.

55 Es abundante la bibliografía que trata este controvertido asunto. Domínguez Ortíz lo señaló con su proverbial capacidad para la síntesis: «El clérigo era el protector natural de su familia». Véase también la citada obra de BENITO AGUADO, en especial las páginas 124-135. 
El hogar de los Quintano era un establecimiento múltiple de complicada estructura. Fernández Quintano, de 31 años de edad, y su cónyuge -con el concurso de un amanuense contratado para los quehaceres del despacho profesional- asociaban, en el seno de un inmenso edificio en el que ellos usufructuaban un espacio cercano a los $1.500 \mathrm{~m}^{2}$, la presencia de otros dos núcleos familiares corresidentes. Por una parte, bajo sus mismos techos, descubrimos a la madre de él, Andrea Pérez, y a una hermana, María Fernández Quintano, viuda de 58 años y soltera de 28 , respectivamente. En el entresuelo, por otra, tenía sus estancias el citado clérigo, quien, a su vez, gozaba de la presencia de su madre viuda, Lucía González, de 64 años, un sobrino de 17, «estudiante de gramática», y una criada, soltera, de 31 años. El arrendamiento eran 500 reales/año, «advirtiendo que la Vivienda principal que yo ocupo -dijo Manuel Fernández Quintano- sale en solos trescientos y el resto sobre ellos hasta completar la anterior partida se Contribuye por otros dos vecinos, a quienes tengo subarrendada havitazión en los quartos entresuelos de dha Casa». En su memorial, don Martín nos advierte de las personas a su cargo, de sus empleos -beneficiado en San Cosme y responsable de una capellanía- y de en dónde vive -pagaba 15 ducados al año por los entresuelos de la casa subarrendada por su tío a otro eclesiástico, don Agustín Fernández Valdivielso, racionero de la Catedral-. A don Martín se le computan ingresos anuales cercanos a los 1.500 reales, un $41.4 \%$ de lo entrado en el hogar referido. A don Manuel, después de efectuado el pago de la renta del oficio que desempeñaba, 300 reales/año, se le calcularon por parte de los peritos 2.200 reales de útil -él señaló únicamente 140 ducados-, una cantidad no muy excesiva «considerando -como el mismo narraba en su memorial catastral-ser moderno en él, adventicia la Dependenzia, cortedad de negozios, crecido número de Procuradores que ay y lo que se trabaja y desembolsa de anticipación en Despachos y diligencias que no se cobran» ${ }^{56}$.

Los otros cuatro ejemplos se distribuyen, a partes iguales, entre clérigos que aportan alrededor de un 10 a un $15 \%$ de los ingresos anuales, individuos encuadrados, el sobrino, en niveles medios y bajos de la nómina eclesial, capellanes del número y medio racioneros parroquiales, y quienes respondían a otro patrón completamente diferente dado que a ellos se debía la mitad del aporte económico anual, en su calidad de canónigos y racioneros de la Catedral. Tie-

\footnotetext{
56 ADPB. Catastro, Memoriales, M, Libro 346, folio 417 y M, Libro 349, folio 469. El hogar estaba conformado por tres núcleos familiares. En primera instancia, el matrimonio principal, bajo cuya autoridad se alineaban la madre de don Manuel, viuda, y una hermana, soltera, y un amanuense. En último término -ubicado en los entresuelos pero en corresidencia con los anteriores núcleos- el clérigo, quien daba cobijo a su madre, también viuda, a un sobrino, «estudiante de gramática» (se reitera hasta la saciedad la fórmula del clérigo que asila a familiares que aspiran a entrar en la carrera eclesiástica) y una criada soltera.
}

Hispania Sacra, LIX

120, julio-diciembre 2007, 563-594, ISSN: 0018-215-X 
nen los cuatro un denominador común. El clérigo que acoge era miembro del Cabildo -canónigo o racionero-, de manera que se entreve una alianza funcional de parentesco de proyección institucional y profesional, además de solidaria desde el punto de vista humano. El análisis detallado de los ejemplos incluidos en ambos modelos nos brinda la ocasión de contrastarlo con lo sucedido con los padres y allanará el camino para lo acaecido con otros parientes.

Nos encontramos con otro ejemplo de convivencia en el seno de un hogar múltiple Don Diego era canónigo coadjutor en la Catedral y beneficiado en Juarros. Don Martín capellán de número, también en la Iglesia Metropolitana. Ocupaban un edificio, propiedad de la Mesa Capitular, por el que pagaban anualmente 550 reales, cantidad que les permitía usufructuar, y sin más compañía, aproximadamente $173 \mathrm{~m}^{2}$ de suelos habitables. El canónigo obtuvo en 1751 casi 9.000 reales de ingresos, mientras que el capellán del número sobrepasaba en poco los 1.500 reales -un $14.4 \%$ de la economía familiar-. Descontados los gastos habituales (salarios, alquiler, subsidio, excusado, etc.), al hogar le quedaba un respetable volumen de dinero y productos en especie -alrededor de los 8.800 reales-. Cada uno de ellos aportaba a la corresidencia otros hermanos y sobrinos. Descuella Don Martín por haber acogido a su lado a dos sobrinos de corta edad, 8 y 11 años, respectivamente, «hermanos a quienes asistimos en todo lo necesario» 57 .

Castilla se hallaba al frente de un hogar sin estructura familiar en el que cabían, dentro de un inmueble propiedad también del Cabildo catedralicio, sito en la calle La Paloma o Cerrajería, siete personas -el canónigo, tres sobrinos, uno de ellos clérigo, y tres criadas-. Uno de esos sobrinos, el licenciado don José González Carrera, era beneficiado de media ración en San Martín, abogado de la Real Chancillería de Valladolid y capellán en la Congregación de La Criaçón y del hospital de San Lázaro. Señaló reiteradamente vivir «con su tío don Felipe Carrera», canónigo en la Catedral, beneficiado en San Martín y capellán mayor en San Enrique (Catedral). Las tres habitaciones o pisos del edificio que ocupaban posibilitaban el acceso a casi $500 \mathrm{~m}^{2}$ de suelos, espacio complementado con un jardín de $100 \mathrm{~m}^{2}$, preñado de árboles frutales y flores. A don Felipe se le pueden adjudicar ingresos por valor de 13.500 reales. Don José, mucho más modesto, sobrepasaba en poco los $1.500-10.5 \%$ de la contabilidad del susodicho hogar-58.

57 ADPB. Catastro, Memoriales, D, Libro 349, folio 38.

58 ADPB. Catastro, Memoriales, Ph, Libro 349, folios 562-563 y J, Libro 349, folio 381. Como era norma habitual entre los clérigos de la ciudad, ocupaban el inmueble en exclusiva, sin molestias de ningún otro vecino en las mismas escaleras de acceso y con una distribución clasista del espacio interior -el arriba y el abajo y las estancias intermedias diferenciaban profundamente a los amos y los criados-. 
Don Román García Velarde y don José Rodríguez ${ }^{59}$, por una parte, y don Juan y don Santiago Barcina ${ }^{60}$, por otra, personifican la existencia de un modelo con convivencia en igualdad -me atrevo a calificarlo de «tiamiento» o hermanamiento funcional de carácter ascendente-, modelo según el cual dos canónigos o racioneros de la Catedral corresidían en un mismo edificio, compartían servicio domésticos y atrezzo hogareño y mutuamente se hacían compañía, en hogares sin estructura familiar constituidos por 5 ó 6 personas, entre los cual se detalla la presencia de 2 a 4 criadas. Todos ellos percibían de la Mesa Capitular de la Catedral unas prebendas más o menos similares, alrededor de los 8.500 reales al año, de manera que, deducidos los gastos esenciales, disponían de un útil medio cercano a los 15.000 reales. La documentación recopilada para don Román García Velarde nos permite acercarnos también a sus niveles de fortuna. El IPM que se elaboró después de su óbito fue uno de los más suculentos de los hallados para el Burgos de mediados del siglo XVIII, con una tasación superior a los 270.000 reales $^{61}$. Don Román siempre confió en su sobrino, nombrado testamentario en sus últimas voluntades $(1766)^{62}$. En esta misma senda se encontraba el hogar de don Nicolás Gayangos, capellán, músico y veedor de granos en Las Huelgas, quien alojaba junto a él a un sobrino, don Nicolás Martínez Gayangos, capellán en la misma institución, y a una criada ${ }^{63}$.

Los hermanamientos suponían el $19.4 \%$ de los casos de clérigos dependientes analizados, con un predominio evidente de la corresidencia con el sexo masculino (71.4\%) y del beneficiado (62.5\%) sobre el canónigo.

Gertrudis Gete y Ana Martínez de los Huertos eran viudas, de edad madura aunque no excesivamente ancianas -de promedio 50 años-, un útil anual alrededor de los 4.500 reales y un hermano, junto a ellas, beneficiado en una parroquia de la ciudad -de sus ingresos procedía entre el 60 y el $75 \%$ de los asientos en la contabilidad familiar-. Diferían, empero, en el estamento -Gertrudis era pechera y Ana hidalga- y en las dimensiones de los suelos que tenían habitables en sus respectivas viviendas. La casa-mesón de Gertrudis superaba los $400 \mathrm{~m}^{2}$, en la calle Cantarranas la mayor, mientras que la noble y su hermano el clérigo, auxiliados por un ama, viuda, no superaban los $125 \mathrm{~m}^{2}$. Don Plácido

${ }^{59}$ Ibídem, R, Libro 349, folios 583-584 y J, Libro 349, folio 412. Don José estaba muy orgulloso de vivir «en compañía de don Román García Velarde, su tío».

${ }^{60}$ Ibídem, J, Libro 349, folio 405. Además del sobrino citado, hallamos otro más, ausente, «estudiante en el colegio mayor de San Bartolomé de Salamanca», quien recibía asistencia de sus parientes.

${ }^{61}$ AHPB. Justicia Municipal. José Álvarez. Legajo 987 (1786), folios 9-85. Véase F. J. SANZ DE LA Higuera (2006), pp. 227-228 -anexo bibliográfico-.

62 AHPB. PN. Juan Antonio Fernández Guilarte. Legajo 7031 (16 de enero de 1766), folios 44-45. Véase F. J. SANZ DE LA Higuera (2005) -anexo bibliográfico-.

${ }^{63}$ ADPB. Catastro, Memoriales, N, Libro 349, folios 636-637.

Hispania Sacra, LIX

120, julio-diciembre 2007, 563-594, ISSN: 0018-215-X 
Benito Gete, hermano de Gertrudis, se afanaba en compatibilizar sus quehaceres como beneficiado y mayordomo en San Lesmes, administrador de la obra pía de don Nicolás Barrieta - ubicada en dicha parroquial- y la titularidad de una capellanía fundada por don Jerónimo Ruiz de Camargo, beneficiado en San Lesmes y obispo de Córdoba ${ }^{64}$. Don Manuel Martínez de los Huertos, hermano de doña Ana, repartía su tiempo entre la parroquia de Nuestra Señora de La Blanca y la Congregación llamada La Real. En su memorial se detalla que ocupaba «vivienda con su hermana doña Ana Martínez de los Huertos en casa gratuitamente cedida por la Dignidad Arzobispal [en la plaza del Sarmental] en atención a los servicios de don Juan Anejo, su difunto marido» ${ }^{65}$. En su testamento de 1738 dejó a sus hermanos, incluida Ana, como sus herederos universales «para que por yguales partes lo aian y hereden» ${ }^{66}$.

Don Pedro Campos, procurador del número (Plaza de Santa María), don Mateo Hojas, beneficiado de San Lorenzo (plaza del Huerto del Rey), don Andrés Pérez Bracho, canónigo (calle Alta o Tenebregosa) y don Juan López Villalobos, labrador (San Esteban), eran los cabeza de hogar en que se encuadraban don Antonio Campos, medio racionero en la Catedral y beneficiado en Frías, don Pedro Hojas, beneficiado en San Lorenzo, don Bernardo Pérez Bracho, canónigo, y don José y don Manuel López Villalobos, beneficiados en San Esteban y San Martín, respectivamente. Todos ellos estaban encuadrados en los estamentos privilegiados, sus hogares eran, salvo puntuales excepciones, múltiples o ensanchados -con 2 ó 3 criados contratados-, sus niveles de renta eran elevados, aunque diversos, y la presencia del clérigo aportaba alrededor del $50 \%$ de los ingresos de la unidad doméstica. Una breve semblanza de cada uno de tales hogares nos brindará la oportunidad de profundizar en los detalles.

El hogar de los Campos estaba constituido por el matrimonio, cuatro hijos, el clérigo, un amanuense para el trabajo de despacho y una criada para el servicio doméstico. Los 4.581 reales del procurador se complementaban con los 2.926 del clérigo. $530 \mathrm{~m}^{2}$ de suelos habitables les brindaban un magnífico espacio para el confort, las relaciones familiares y cierto grado de intimidad ${ }^{67}$. Acordes a esos niveles de renta aparecen los niveles de fortuna. Los 16.300 reales del IPM de don Pedro delatan la tragedia de aquellos burócratas que no vivían excesivamente desacomodados pero tenían serios problemas patrimoniales y un raquítico peso social. En sus últimas voluntades (1762) solicitó que su sepultu-

\footnotetext{
64 Ibídem, G, Libro 345, folio 742.

65 Ibídem, A, Libro 344, folio 119 y M, Libro 349, folio 442. Los servicios prestados a las instituciones eclesiásticas devengaban privilegios residenciales muy suculentos $\mathrm{y}$ «a vita». Los encontramos en el Burgos de mediados del XVIII asociados a viudas de alta alcurnia, cuyos cónyuges trabajaron para los Arzobispos o para la Catedral (mayordomía, obras pías, etc.).

${ }^{66}$ AHPB. PN. Lorenzo Antonio de Zubillaga. Legajo 7072 (23 de junio de 1738), folios 278-281.

${ }^{67}$ ADPB. Catastro, Memoriales, P, Libro 347, folio 117 y A, Libro 348, folio 38.
} 
ra fuera «la más humilde de dha Iglesia (Santa Águeda)», signo evidente no de su hipocresía social cuanto del convencimiento personal de su pequeñez y modestia. Su testamento fue de los pocos que únicamente ocupó un par de caras, un folio, indicio de precariedad económica ${ }^{68}$.

Los Hojas vivían hermanados y en compañía de un criado y de una criada viuda, a cuyo cargo se encontraba una hija soltera -nos hallamos, por tanto, ante un hogar múltiple (5c) por razones laborales-. La casa que los acogía, dotada de $278 \mathrm{~m}^{2}$, respondía a la típica estructura de los edificios de la ciudad -entresuelo con portal, un cuarto y caballeriza, dos viviendas- con tres cuartos cada una $-y$ un soleador en lo alto-. Entre ambos controlaban un útil ligeramente superior a los 7. 000 reales $^{69}$, lejano evidentemente de los casi 19.000 reales que los hermanos Pérez Bracho percibían de sus prebendas en la Catedral. El hogar sin estructura familiar que ellos lideraban, bajo cuya férula aparecen dos criadas, no estaba reducido a la estrechez vital ni en lo económico ni en lo habitacional -pagaban 550 reales al año por $330 \mathrm{~m}^{2}{ }^{70}$. Fallecidos los progenitores, la solidaridad y la ayuda mutua eran herramientas imprescindibles para sentirse arropados y afrontar con mayor garantía de éxito la soledad de la urbe. En sus respectivos y reiterados testamentos, tanto los Hojas como los Pérez Bracho -se repite en otros muchos casos- se dejaron uno a otro como herederos universales e incluso ordenaron que sus cuerpos fueran depositados en la misma sepultura, de manera que su cohabitación se prolongara más allá de la propia existencia terrena ${ }^{71}$.

En San Esteban, en una casa de $140 \mathrm{~m}^{2}$, estaban instalados los López Villalobos y Sagredo. El hogar, múltiple por hermanamiento, estaba habitado por Juan, su cónyuge, Ana López, sus cuatro hijos, y varias de las estancias por tres hermanos del labrador, dos de los cuales eran clérigos, una criada y dos criados

${ }^{68}$ AHPB. PN. Nicolás Martínez Vivanco. Legajo 7147 (1763), folios 141-182 (IPM) e Ibídem, Nicolás Martínez Vivanco, Legajo 7147 (9 de diciembre de 1762), folio 103.

${ }^{69}$ ADPB. Catastro, Memoriales, M, Libro 349, folio 466 y P, Libro 349, folios 567-568. Don Mateo se ocupaba en los quehaceres propios de varias capellanías. Don Pedro era beneficiado en San Lorenzo y capellán pluriempleado.

70 Ibídem, A, Libro 348, folios 33-34. Controlaban el inmueble en exclusiva.

${ }^{71}$ Para los Hojas, AHPB. PN. José Maestre. Legajo 7064 (7 de marzo de 1750), folios 278-283 y Legajo 7063 (7 de diciembre de 1747), folios 370-371; Francisco de Villafranca. Legajo 7090/2 (30 de octubre de 1752), folios 318-319 y Legajo 7090/2 (28 de octubre de 1752), folios 312-313; José Julián Villar. Legajo 7091 (25 de mayo de 1753), folios 64-67 y Nicolás Martínez Vivanco. Legajo 7147 (25 de enero de 1763), folios 132-134. Los Pérez Bracho en Ibídem, Nicolás Martínez Vivanco. Legajo 7146 ( 2 de junio de 1765), folio 723 y Alonso de Melo Peña. Legajo 7225/2 (15 d enero de 1791), folios 44-49. Otro excelente ejemplo de corresidencia en la vida y en la muerte, ocupando una misma casa y una misma tumba, lo encontramos en los hermanos Zaldivar, beneficiados en San Cosme y San Pedro de la fuente, respectivamente. Ibídem, Jacinto Álvarez. Legajo 7123/1 (6 de septiembre de 1773), folios 287-288 y Legajo 7218 (4 de mayo de 1783), folios 282-286.

Hispania Sacra, LIX

120, julio-diciembre 2007, 563-594, ISSN: 0018-215-X 
para la labranza -los otros animales, un par de mulas y un par de machos de labranza, los dejaré a un lado, de momento-. En el memorial de los eclesiásticos se leen textualmente que «la vivienda, con quatro hermanos» la tenían pro-indiviso como herederos de sus padres. De los cuatro hermanamientos aducidos es el que presenta unos peores indicativos económicos y una mayor estrechez

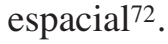

Don Francisco Díaz de la Peña, canónigo, acompañaba a su cuñada, doña Teresa Antonia de Sisniega, viuda de don José Díaz de la Peña, sus tres hijos y el personal doméstico - dos criadas y un criado-. El enorme caserón que ocupaban en la plaza del Huerto del Rey, con casi $600 \mathrm{~m}^{2}$ de suelos habitables, les permitía mucha autonomía. La canonjía producía el $91.9 \%$ de los ingresos de este extenso hogar, (4c)7, en que residía don Francisco, quien dijo vivir con su hermana doña Teresa. Esta lo hubiera pasado muy mal, como era lo común para muchas viudas de la ciudad 73 , de no ser por el concurso del clérigo. Las rentas, muy devaluadas, de varios juros no daban para mucho ${ }^{74}$. En su testamento (1764), doña Teresa señaló a don Francisco como su cabezalero y testamentario, de modo que él se ocupó de tomar todas las decisiones imprescindibles en el «Acompañamiento de Entierro, Missas y sufragios que se han de hazer y celebrar por mi Alma, para que lo disponga según y cómo le parecieren» 75 .

Don Ventura Ruiz de Quintana, canónigo también, pagaba 400 reales al año, la mitad del alquiler de una casa en la elitista plaza del Huerto del Rey, un edificio contratado por el licenciado don Gregorio Rodríguez de Ubierna, abogado de los Reales Consejos, cónyuge de su hermana, doña Maria Manuela Ruiz de Quintana, en cuya casa y compañía veía discurrir su existencia. El hogar así conformado, un múltiple (5d)13 por hermanamiento, tenía las dependencias del inmueble repartidas entre el matrimonio, sus siete hijos y una criada, por una parte, y el clérigo, un criado estudiante y una criada, por otra. Las dimensiones de la vivienda, alrededor de $\operatorname{los} 750 \mathrm{~m}^{2}$, y el alcance anual generado, entorno a los 16.500 reales/año -el clérigo aportaba el $49.6 \%-$, colocan a sus protagonistas en un lugar privilegiado de la sociedad burgalesa ${ }^{76}$.

En Las Huelgas, don José Valpuesta no tenía ningún reparo en aseverar que vivía con su hermano don Agustín. Ambos desarrollaban sus quehaceres profe-

72 ADPB. Catastro, Memoriales, J, Libro 345, folios 451-456 y J, Libro 349, folios 378-379.

73 Véase F. J. SANZ DE LA Higuera (2005) -anexo bibliográfico-.

${ }^{74}$ ADPB. Catastro, Memoriales, T, Libro 347, folio 453 y F, Libro 349, folio 175.

75 AHPB. PN. Francisco de Villafranca. Legajo 7096/1 (26 de marzo de 1764), folios 124-125. Véase SANZ DE LA HigUeRa (2005) -anexo bibliográfico-.

${ }^{76}$ ADPB. Catastro, Memoriales, G, Libro 345, folio 43 y T, Libro 349, folios 595-596. El edificio era ocupado en exclusiva por el hogar de abogado y el canónigo. El clérigo abonaba la mitad de la renta. 
sionales en el Monasterio de Las Huelgas. Su economía doméstica estaba muy bien dotada, lo que les permitía tener con ellos a su madre, viuda, de 60 años, y a una hermana de 32 que ejercía -como era usual en estos hogares- labores de servicio ${ }^{77}$.

El $11.1 \%$ restante de los casos hallados de clérigos dependientes, cobijados bajo la férula de un pariente o persona responsable, tiene en la existencia de un tutor, un primo o un sobrino su vía de canalización.

Don Benito Ochoa y Cazares nos dejó muestras de su agradecimiento y de sus circunstancias vitales a través del memorial catastral, que de su mano redactó y rubricó, cuando afirmaba «Vivo con Pedro López de Para, mi tutor, desde hace treinta i quatro años». Era huérfano desde los dos años y encontró acomodo para su persona y solución a sus desgracias en la casa de un pariente lejano que le mantuvo y le dio estado. Sus actividades como beneficiado en San Lorenzo y en la capellanía de los Sánchez de Valencia en San Lesmes, además de algunas rentas «en diferentes lugares» de la provincia, le permitían aportar, después de pagados los 400 reales de renta de servicio del beneficio que usufructuaba y satisfechos los alimentos que le daba a su madre y hermanas, un $36 \%$ de los ingresos de la economía familiar que lo había acogido. Don Pedro, en su calidad de procurador del número del Tribunal del Real Adelantamiento de Castilla y representante del duque de Medinaceli «en la defensa de sus pleitos en el dho Tribunal», presidía, en la elitista calle Cantarranas la mayor, un hogar (4c)6 -conformado por el matrimonio, el clérigo, una hermana de la mujer, una criada y un escribiente-, que, sin duda, estaba muy bien acomodado sobre los casi $700 \mathrm{~m}^{2}$ que de suelos habitables tenía el inmuebles que habían alquilado. Los 66 años de don Pedro, en 1751, se complementaban perfectamente con los 36 de don Benito. Era éste el hijo que al parecer nunca pudo tener -al menos en el memorial de Catastro no consta que hubiera elevado a doña Isabel Álvarez de Castañeda a la categoría de madre- ${ }^{78}$.

El canónigo García Ramos ocupaba una estancia, «sin alquiler» se especifica de manera puntual, en la «vivienda de don Gregorio Bernáldez». Su relación de parentesco no se especifica pero la tutoría es evidente. La también elitista y céntrica plaza del Sarmental, esquina con la calle La Paloma, era la residencia de este conocido y activo mercader de paños y sedas, que decía estar "sin criados ni oficiales como consecuencia del estancamiento comercial». $230 \mathrm{~m}^{2} \mathrm{al}-$ bergaban un típico hogar ensanchado, (4c)5, en el que el matrimonio de comerciantes, una hija de muy corta edad, el clérigo y una criada -que recibía comida, habitación y 88 reales al año-, se repartían por el espacio y se mante-

77 ADPB. Catastro, Memoriales, A, Libro 349, folio 605 y J, Libro 349, folio 628.

78 Ibídem, P, Libro 347, folios 160-161 y B, Libro 348, folios 56-59.

Hispania Sacra, LIX

120, julio-diciembre 2007, 563-594, ISSN: 0018-215-X 
nían con el útil que ambos, el mercader y el clérigo, que aportaba el $76.8 \%$ de los ingresos familiares, generaban en sus respectivos empleos habitualmente ${ }^{79}$.

En los testamentos de los tutores de los clérigos señalados -sea Gregorio Bernáldez o Pedro López de Para- no se hacen absolutamente ninguna mención, ni siquiera de pasada, a esas personas con las que convivieron durante tantos años, individuos que no aparecen ni como testamentarios ni como merecedores de alguna manda y mucho menos como herederos universales ${ }^{80}$.

El hogar que comandaba el capiscol y canónigo catedralicio Zamora Huidobro, y bajo cuya férula se alineaban varios primos, dos de ellos clérigos, era un establecimiento doméstico muy singular. Don Diego, el capiscol, había traído a su casa y compañía a don Bartolomé, canónigo coadjutor, don Juan Ramón, presbítero y arcipreste de Losa, doña Ana, doña Catalina y doña Juana, hermanas de los clérigos, una sobrina, un paje estudiante y dos criadas de servicio. Todos ellos afirmaron taxativamente vivir «en compañía» de su primo en la Pellejería. La casa que tenían alquilada, y por la que pagaban anualmente 440 reales, les permitía disfrutar, en una zona privilegiada y cercana a la Catedral, de $420 \mathrm{~m}^{2}$ de suelos para la convivencia o la intimidad, según fuera el deseo de sus ocupantes. La economía del hogar rebosaba salud. El alcance anual puede ser estimado en un montante cercano a los 30.000 reales -recuérdese que el promedio de la ciudad eran 1.500 reales/año-, cantidad en la que los clérigos dependientes aportaban un $44 \%$ del total. Este tipo de hogares era la rampa de lanzamiento del futuro estado de los parientes acogidos, en especial del de los eclesiásticos, que heredaban los empleos y los bienes del pariente acogiente ${ }^{81}$. Lamentablemente no disponemos de sus IPM ${ }^{82}$.

Los espectaculares niveles de renta de los canónigos y dignidades contrastan con la sobriedad y la estrechez de Manuel Ruiz y don Miguel García, labrador y beneficiado parroquial, vecinos ambos de Villatoro. Con un útil anual raquítico, poco más de 1.600 reales, el hogar en que convivían los anteriormente aludidos era fruto de un acuerdo tácito de corresidencia. Don Miguel señaló que «la casa es de los sobrinos en que viven sin separación muy conformes; y el cura no tenía que comer ni forma de vivir. Manuel Ruiz, su sobrino, que hace tres años que está con ellos, le arrendó los bueyes y le ha comprado la huebra de caba-

79 ADPB. Catastro, Memoriales, G, Libro 345, folio 22 y Ph, Libro 349, folio 566.

${ }^{80}$ Gregorio Bernáldez en AHPB. PN. José Guadilla. Legajo 7131 (22 de diciembre de 1775), folios 232-233 y Pedro López de Para en Ibídem, Francisco de Villafranca. Legajo 7093 (8 de junio de 1757), folios 109-110.

${ }^{81}$ ADPB. Catastro, Memoriales, D, Libro 349, folio 44, B, Libro 348, folio 48 y J, Libro 349, folios 416-417. El inmueble, por descontado, lo ocupaba este hogar en exclusiva.

${ }^{82}$ Estimo que el capiscol Zamora Huidobro dispuso de un patrimonio ligeramente superior a los 100.000 reales, IPM que estaría en la tónica de lo recopilado para otras dignidades catedralicias. 
llos y veinte i tres ovejas y antes no tenían que comer y ahora les sobra». La labranza de Manuel mejoró substancialmente con el aporte de animales que le prestó o compró clérigo. El clérigo pudo salir de la soledad y de la indigencia merced a la corresidencia con su pariente ${ }^{83}$.

Para finalizar, referiré las peripecias de don Blas de Illana, beneficiado en La Blanca, que constituyen, a mi juicio, un paradigma de los asertos que se han mantenido y se pretenden demostrar. Al final de su testamento (1752), adjuntó una «Memoria» en la que, entre otros asuntos muy jugosos, se nos informa de que «por el acçidente de melancolía morvo que me acometió en el mes de julio de el año de mil seiscientos y quarenta y nueve, que me duró Cosa de un año, me pasé a Vivir en casa deel referido mi Pariente Dn Joseph Herrera ${ }^{84}$, contemplando me serviría de alivio la Comunicazión frequente con dho mi pariente y Su familia, y precaviéndome de el peligro a que estaban expuestas mi alaxas de plata si las dexava en mi casa, las llevé a casa de el referido Dn Joseph Herrera, y para efecto de que me las guardasen en sitio acomodado entregué al zitado Dn Joseph Herrera y su muxer las (...) alajas de plata (...) todas las quales alajas son bien conocidas por las personas que han tratado en mi casa». Repuesto de sus patologías, «aviéndome Vuelto a mi casa a Vivir a mediados de septiembre de este año de Zinquenta $y$ dos, les he enviado algunas nuevas para que me las embien [y] han respondido que me las entregarán pasando a su casa a recivirlas, y no ha llegado el caso de pasar yo a su casa (...) por no permitírmelo el tiempo y mi delicadeza, por lo qual están en su poder». Bastante enfadado, don Blas añade «que en todo el tiempo que viví y havité en casa de el referido Dn Joseph Herrera fui servido y asistido por mis Criadas, a quienes pagué sus salarios y alimentos como también los míos de comida y bebida y todos los demás gastos ordinarios como la luz, la bandera, medicinas y demás cosas necesarias, Útiles y Utilitarias, y en los dos años pagué la mitad de el carvón que se gastó en dha casa, en la que no ocupé Cuarto determinado reservado para mí, porque aunque el año primero y no entero dormí en la Sala (...) y lo demás de el tiempo dormí en sitio que no es de estimación» ${ }^{85}$. La relación no era idílica. La información que nos suministra el clérigo nos permite considerar, aún en el extremo de una convivencia inestable y problemática, cuáles eran los términos de la cohabitación y qué circunstancias se concitan en el contraste entre vivir en hogar independiente y acogerse a la benevolencia y la solidaridad de los familiares. De hecho, en su declaración catastral seña-

${ }^{83}$ DPB. Catastro, Memoriales, M, Libro 346, folios 732-736 y M, Libro 349, folios 450-453.

${ }^{84}$ Ibídem, J, Libro 345, folio 529 (don José Herrera Tomé).

${ }^{85}$ AHPB. PN. Cristóbal Alonso de Soto. Legajo 7152/2 (1 de diciembre de 1752), folios 18-19.

Hispania Sacra, LIX

120, julio-diciembre 2007, 563-594, ISSN: 0018-215-X 
ló de forma puntual que vivía «en la casa de la Plaza Mayor, esquina con Trascorrales (...) en la habitazión de arriba tiene los ajuares, aunque ahora -por sus achaques y edad [61 años]- se encuentra con unos parientes» ${ }^{86}$.

\section{A MODO DE CONCLUSIÓN}

La inmensa mayoría de los clérigos de Burgos a mediados del siglo XVIII vivían muy cómoda y confortablemente en sus viviendas de alquiler. Algunos comandaban hogares múltiples, por razones de solidaridad familiar o por causas laborales. Ejemplos de estos asertos son los establecimientos domésticos retratados en don Cayetano Gómez (Villimar) ${ }^{87}$, don Pedro Calderón (Pellejería) ${ }^{88}$, don Juan Antonio Ruiz Sagrado ${ }^{89}$, don Juan Antonio Garma de la Puente ${ }^{90}$, don Diego Haedo (San Juan) ${ }^{91}$ o don José Gil (Abades) ${ }^{92}$. Empero, algunos eclesiásticos, y no necesariamente de bajo rango y escasas rentas, cohabitaban bajo la atenta mirada de algún pariente que los tenía acogidos en sus casas. La mitad de ellos no habían salido aún de casa de sus padres. Un segmento muy importante, cuatro de cada diez (24.9\%), estaban hermanados, corresidiendo en compañía de hermanos o cuñados. A la postre, con otros parientes colaterales (primos, sobrinos, tutores con un grado de parentesco no especificado) hallamos a un $10 \%$ de ellos. Una gran mayoría, el $86.2 \%$, eran clérigos de rango medio y bajo, integrados en los cabildos parroquiales de la ciudad o de sus cercanías, individuos que vivían a la sombra de sus padres y que se mantenían merced a su ayuda. No obstante, un $13.8 \%$ estaban integrados en las estructuras más altas de la Catedral, en especial en sus canonjías, y cohabitaban con familiares cercanos en régimen de igualdad. Conformaban hermanamientos para la mutua y solidaria ayuda en el laberinto urbano, compartiendo, a la postre, estancias, mesas y manteles.

\footnotetext{
${ }^{86}$ ADPB. Catastro, Memoriales, B, Libro 348, folio 63. «Hace más de dos años que no dice misa por sus achaques», por lo cual no ganaba apenas nada en las capellanías y obtenía aproximadamente 70 ducados en la parroquia porque «le hacen el favor de sacarle el beneficio de las misas».

${ }^{87}$ Ibídem, C, Libro 348, folios 224-235 (hogar múltiple ascendente).

88 Ibídem, P, Libro 349, folios 569-570 (hogar múltiple por hermanamiento). En el memorial de su prima, doña María Sánchez de Cos, se dice que «la vivienda principal, su entresuelo y parte del patio lo ocupa su primo don Pedro Calderón, beneficiado en San Esteban, con sus hermanos y demás familia». El edificio disponía de tres altos con patio en medio y un entresuelo con carboneras, caballerizas y trojes. Ibídem, M, Libro 346, folios 290-291.

${ }^{89}$ Ibídem, J, Libro 349, folio 385 (hogar múltiple por hermanamiento).

${ }^{90}$ Ibídem, J, Libro 349, folio 349 (hogar múltiple por motivos laborales).

91 Ibídem, D, Libro 349, folio 37 y V, Libro 347, folio 542 (ídem).

92 Ibídem, J, Libro 349, folio 406 y F, Libro 344, folio 855 (hogar múltiple descendente).
} 
La dialéctica de los alquileres urbanos y del ir y venir de los clérigos mantuvo en un perpetuo fluir la existencia cotidiana de estos individuos, como lo demuestra la peripecia vital de don Pedro Celestino Tomé Carrera. De casa de su padre, don Pedro Tomé González, se fue a Roma, a cursar estudios eclesiásticos. Al volver de la sede pontificia retornó a la casa de la plaza del Sarmental. Las tensas relaciones con su progenitor le obligaron a tomar a renta un inmueble independiente. Sus prebendas como arcediano de Burgos en el seno de la Cabildo catedralicio bien se lo podían permitir ${ }^{93}$. Sólo se puede cohabitar con un pariente cuando por afecto, por amor fraternal o merced a una mutua y bilateral colaboración se hace viable el compartir un espacio habitable sin excesivos traumas ni conflictos. La convivencia siempre es difícil y puede llegar a ser tensa y espinosa. ¿Anhelaban los clérigos colocados bajo la férula de sus padres, tíos o tutores vivir en su propia casa, de una manera independiente? ¿Si aún seguían atados a sus familiares era por una mezcla de comodidad funcional, incapacidad económica e inercia parental?

\section{ANEXO BIBLIOGRÁFICO}

F. J. SANZ DE LA HigueRA: «Familia, hogar y vivienda en Burgos a mediados del siglo XVIII. Entre cuatro paredes, compartiendo armarios, camas, mesas y manteles», Investigaciones Históricas, núm. 22, Valladolid (2002a), pp. 165-211.

F. J. SANZ DE LA Higuera: «Alojamiento de tropas en Burgos a mediados del siglo XVIII. Cuarteles, alquileres y hospitales para el Regimiento de Inválidos de Cataluña (1748-1753)», Actas de las XI Jornadas Nacionales de Historia militar, tomo I, Sevilla, (2002b), pp. 335-360.

F. J. SANZ DE LA HigueRA: «A la sombra de la muerte: Viudez espléndida, viudedad paupérrima a mediados del Setecientos», Cuadernos de Investigación Histórica, núm. 22, Madrid (2005), pp. 431-461.

F. J. SANZ DE LA HigUERA: «Producción, venta y consumo de lácteos en el XVIII burgalés», Stvdia Historica, Salamanca, (2006) (en prensa).

R. TORRES SÁNCHEZ: «Estructura familiar y grupo doméstico en la España del siglo XVIII», Cuadernos de Investigación Histórica, núm. 13, Madrid, (1990), pp. 189-215.

${ }_{93}$ Encontramos información sobre él en ADPB. Catastro, Memoriales, P, Libro 347, folios 92-96. 